\title{
THE SOUTH'S AMENDED BARRATRY LAWS: AN ATTEMPT' TO END GROUP PRESSURE THROUGH THE COURTS
}

IN the middle 1950's seven southern states suddenly discovered a need to reinvigorate and extend existing champerty, maintenance and solicitation rules. ${ }^{1}$ The flurry of legislation came on the heels of the Supreme Court's decision in Brozm v. Board of Education ${ }^{2}$ in which five civil rights organizations appeared as amicus curiae. ${ }^{3}$ The two events were not unconnected. The action of the legislatures was a vigorous political response to the success of these organizations before the courts. ${ }^{4}$ The validity of that response was seriously questioned in $N A A C P$ v. Button, ${ }^{5}$ where the Supreme Court struck a Virginia solicitation statute ${ }^{6}$ which seemed drawn to impede the effectiveness of those very groups of civil rights litigators who had been so effective in prior legal assaults on segregation. That the states attempted to control their conduct was not surprising, for the goals of these litigators are directly opposed to those of the majoritarian forces in control of the states' political machinery.

Civil rights litigating organizations seek access to the courts primarily for political ends-permanent change in law or social behavior rather than successful prosecution of particular lawsuits over matters of substantial individual

1. See note 32 infra.

2. 347 U.S. 483 (1954), 349 U.S. 294 (1955).

3. The five were the American Jewish Congress, the American Civil Liberties Union, the American Federation of Teachers, the Congress of Industrial Organizations, and the American Veterans Committee. Brown v. Board of Edueation, 347 U.S. 483, 485-86 (1954). Also appearing as amicus curiae was the Assistant Attomey General of the United States. Id. at 485. While neither the National Association for the Advancement of Colored People nor the NAACP Legal Defense and Educational Fund appeared as amicus curiae, they were the joint sponsors of the litigation. Letters from Robert $L$. Carter, General Counsel of the National Association for the Advancement of Colored People, March 15, 1963, and Norman C. Amaker, NAACP Legal Defense and Edueational Fund, March 13, 1963, to the Yale Lawe Jourral, on file in Yale Law Library.

4. Although the legislation was cast in the familiar form of prohibitions of barratry, maintenance, and solicitation, there can be no doubt that it was directed at civil rights organizations (primarily the National Association for the Advancement of Colored People and the NAACP Legal Defense and Educational Fund) and that it was intended to curtail their legal assault on segregated education. Accounts of the legislative history of the Virginis statutes are set forth in NAACP v. Patty, 159 F. Supp. 503, 511-15 (E.D. Va. 1958); Scull v. Virginia ex rel. Comm. on Law Reform and Racial Activities, 359 U.S. 344, 346-47 (1959); James v. Almond, 170 F. Supp. 331, 333-34 (E.D. Va. 1959); and Adkins v. School Bd., 148 F. Supp. 430, 434-42 (E.D. Va. 1957). While the statutes did not mention the National Association for the Advancement of Colored People or the NAACP Legal Defense and Educational Fund by name, one assemblyman revealingly predicted "with this set of bills ... we can bust that organization ... wide open." Scull v. Virginis ex rel. Comm. on Law Reform and Racial Activities, supra at 347 (citing testimony of James Mr. Thomson).

5. 371 U.S. 415 (1963).

6. VA. CodE ANN. $§ \S 54-74,54-78,54-79$ (1958 Replacement). 
interest. ${ }^{7}$ Activities in pursuit of their goals vary from recommendation of expert legal assistance or filing of an occasional amicus brief to the active planning and control of a litigating curriculum. ${ }^{8}$ Control may take the form of extension of legal aid to parties at interest, promotion and prosecution of class suits, and other means of direct participation in sponsored litigation at trial as well as appellate levels. ${ }^{\circ}$ For those organizations which participate most actively at trial, legal activities may be but one facet of a broad educational-political program which includes lobbying before legislatures, speechmaking, picketing and general publicizing of civil rights issues. But achievement of their goals through legislative means has too often proved hopeless: civil rights catises often prove unpopular with dominant forces in the legislatures, whether from their effect alone or because of the identity of those in whose behalf they are advanced. And with legislative relief precluded, civil rights programs must be prosecuted primarily in the courts.

Where the organization seeks to use its access to the courts for the attainment of political ends, direct representation of litigants in sponsored litigation

7. The political character of group legal activities should not be overstressed. Much of the groups' work is entirely charitable-the provision of friendly legal advice to members of the oppressed minorities they represent or minor participation in cases of interest to their constituents.

The best known of the groups are probably the National Association for the Advancement of Colored People, the NAACP Legal Defense and Educational Fund, the American Civil Liberties Union, and The American Jewish Congress. Others include the Jehovali's Witnesses, the Japanese American Citizens League, the American Jewish Committee, the National Lawyers Guild, the Association on American Indian Affairs, the Protestants and Other Americans United for Separation of Church and State, the American Council for Nationalities Service, the Emergency Civil Liberties Committee, the American Committec for Protection of Foreign Born, the Central Committee for Conscientious Objectors, the American Book Publishers Council, the Workers Defense League, and the American Friends Service Committee.

8. Groups employ a variety of techniques to influence judicial decision. Amicus appear ances in cases affecting their interests, the promotion of law review comment favorable to legal theories they wish to advance, and the use of political pressure to secure the appointment of sympathetic judges are among the many. For discussions of the use by groups of the amicus device see Vose, Litigation as a Form of Pressure Gronp Activity, 319 Annals 27-31 (1958); Bernstein, Vohnteer Amicus Curiae in Civil Rights Cases, 1 NYLS Student L. Rev. 95 (1952) ; and Harper \& Etherington, Lobbyists Before the Court, 101 U. PA. L. Rrv. 1172 (1953). On the promotion by groups of law review comment see Schunert, ConstruvTIONAL Politics 70, 72-76, 80-81 (1960). A dramatic example of group use of political pressure to influence judicial appointment is the NAACP's and the American Federation of Labor's successful campaign to block congressional confirmation of Judge John J. Parker's appointment by President Hoover to the Supreme Court. See Truman, THE Governanental Process 492 (1955) ; Hughes, Frget for Freedom 74 (1962); and Ovington, The Walls Came Tumbling Down 251-56 (1947).

9. For comparative studies of certain of the groups, see Comment, Privatc AttarncysGenteral: Group Action in the Fight for Civil Liberties, 58 YaLE L.J. 574 (1949) ; Vose, Litigation as a Form of Pressure Group Activity, 319 Annals 20 (1958); and Ginger, Special Purpose Defense Organizations, 17 Law. Gurlo Rev. 141 (1957). See also Robinson, Organizations Promoting Civil Rights and Liberties, 275 Annals 18 (1951) and table II, Appendix. 
usually is the most effective means of carrying out its program. It some cases, litigation will not occur unless the organization itself in some manner acts to institute litigation, since those harmed by objectionable practices may be unlikely to bring an action, whether through fear or financial disability. And a careful choice of cases for participation by the organization may be required to maximize the use of its limited financial resources. Direct participation, as opposed to participation through the amicus brief, has the advantage of allowing the organization to shape the trial record in a way most favorable to the broad issues it wishes to present. ${ }^{10}$

This fact of direct participation may, however, give rise to dangers of impropriety in litigation appearing to justify substantial state regulation of civil rights litigators. Litigiousness, attorney-client conflicts of interest, and usurpation of political functions by the courts are among the evils which, in other contexts, states have freely regulated. Yet the valuable services performed by these litigators in enforcing federal as well as state rights, and the strong likelihood that legislative objections may arise from the effectiveness of their performance rather than any such dangers may suggest the need for special judicial consideration in evaluating state prerogatives to control civil rights litigators. This comment will seek to develop an approach to these problems by focusing upon the fact situation recently confronted by the Supreme Court in connection with the conflict between the NAACP and the Virginia legislature over the rights of civil rights litigators to function in Virginia. ${ }^{11}$

\section{NAACP Action and Legislative Response in Virginia}

Of all the civil rights litigating organizations, the NAACP and its offshoot, the NAACP Legal Defense and Educational Fund, are perhaps the most important and best organized. ${ }^{12}$ Formed in 1909 to fight racial discrimination in

10. See generally, Comment, Private Attornej's-General: Group Action in the Fight for Civil Liberties, 58 Y ALE L.J. 574, (1949).

11. NAACP v. Button, 371 U.S. 415 (1963).

12. The NAACP Legal Defense and Educational Fund was formed for tax purposes in 1939. (Unlike the Association, the Fund does not engage in propaganda and lobbying activities; therefore, contributions to it are not disqualified as charitable deductions by Irs. REv. CODE OF $1954 \S 170$ (c) (2) (d).) Until 1955, the Fund operated, in effect, as a subsidiary of the Association. At that time, the Fund completely disassociated itself from the Association in order to preserve its tax status. Letter from Robert L. Carter, General Counsel, NAACP, to the Yale Law Journal, Apr. 15, 1963, on file in Yale Law Library.

Today, both the Association and the Fund have extensive legal programs. With an income of $\$ 670,000$ in 1962, the Fund employs nine attorneys, including its Director-Counsel, and keeps two others on retainers. Interview by telephone with Jack Greenberg, DirectorCounsel of the Fund, March 5, 1963. In addition, large numbers of social scientists, economists, and law professors have placed themselves at its disposal. NAACP v. Harrison, 202 Va. 142, 151, 116 S.E. 2d 55, 63 (1960). The Fund receives requests for assistance from lawyers throughout the country. It determines whether or not to grant assistance by consulting a variety of factors: overall strategic considerations, the nature and importance of the issues involved, the status of the case, and the financial resources of the litigant. Where assistance is granted, the litigant's attorney retains primary responsibility for the progress of the case through the trial level, although Fund attorneys may approve pleadings and mo- 
the United States, ${ }^{13}$ the NAACP now has about 380,000 members, more than 1,000 affiliated branches, and an annual income in excess of $\$ 1,000,000.14$ The NAACP has been exceptionally effective in attaining its objectives before the Supreme Court. In the over fifty victorious cases in which the NAACP has participated directly, ${ }^{15}$ it has succeeded in having declared unconstitutional the enforcement by governmental units of such discriminatory practices as segregated education (Brozen v. Board of Education ${ }^{16}$ ), racially restrictive covenants (Shelley v. Kraemer ${ }^{17}$ ), and the white primary (Smith v. Allweright ${ }^{18}$ ).

More significant, perhaps, as an index of NAACP effectiveness in achieving its goals has been the vigorous and concerted political action southern states have taken to impede its further rending of their traditional social fabric. Existing laws have been applied in a discriminatory manner, often to deprive the NAACP of meeting halls, sometimes to impose exorbitant taxes upon its operations or to require registration of its membership lists. Financial obstacles have been imposed through enactment of prohibitive excises on dues and membership fees. Harassment by legislative investigative groups has resulted in sequestration and publication of records and membership lists and slanderous exposure of NAACP officials. Members of the Association have been denied or removed from state jobs, either pursuant to specific legislation or, less open-

tions and take an active part in the preparation of briefs. Appeals are generally handled by Fund attorneys alone. Typically, the litigant's attorney will receive about $\$ 750$ for taking the case through the trial level. Part of this is sometimes paid by the litigant or from the proceeds of a special fund drive. Interview with Jack Greenberg, Director-Counsel of the Fund, in New York City, December 10, 1962.

The Association, since the formation of the Fund in 1939, has been primarily concerncd with litigation which affects itself as a corporate entity. Nevertheless, it continues independently to offer financial and legal assistance in cases involving segregation. At the national level, it employs three attorneys and keeps two others on retainers. Letter from Robert L. Carter, supra. The program's purpose and its current objectives were recently outlined by the Association's general counsel:

Our main purpose is to break new legal ground, e.g., we are attempting to obtain a definitive court ruling on the validity of so-called de facto school segregation; a ruling by the National Labor Relations Board that it is both an unfair labor practice and grounds for revocation of certification under the National Labor Relations Act for a union to discriminate against Negroes in their status as union members or as cm. ployees.

Letter from Robert L. Carter, supra.

13. For histories of the NAACP see Hughes, Fight FOR Frendon (1962) ; Ovington, The Walls Canse Tumberng Down (1947); and Jack, History of the Natronal Association for the Advancement of Colored People (1943).

14. NAACP, REPORT FOR 1961, 18, 79 (1961).

15. Vose, Litigation as a Form of Pressure Group Activity, 319 Ansals 22 (1958).

16. 347 U.S. 483 (1954), 349 U.S. 294 (1955). The Association and the Fund were co-sponsors of the litigation. Ietters from Robert Carter, General Counsel, NAACP, March 15, 1963; and Norman C. Amaker of the Fund, March 13, 1963, to the Yalc Lazw Journal on file in Yale Law Library.

17. 334 U.S. 1 (1948). The Association sponsored the related cases of McGhee v. Sipes, 334 U.S. 1 (1948), and Hurd v. Hodge, 334 U.S. 24 (1948).

18. 321 U.S. 649 (1944). 
1y, by administrative discrimination. ${ }^{19}$ The debilitating virulence of these state attacks has forced the NAACP, in its own defense, to seek relief in those courts where it usually attempts to vindicate the rights of others. And with such cases before them, the courts, especially the Supreme Court, have been able to confront the legislative attacks with a response based upon a constitutionally found freedom of association. ${ }^{20}$ The regularity with which this judicial response has taken the form of striking state measures inhibiting the organizational abilities of the NAACP has led to a continuing search for new devices, more clearly within the realm of local power, to impede the effectiveness of the Association.

One route to control of the judicial response has utilized the ability of the state, through political means, to pressure the President into appointing judges obviously resistant to the integration process. ${ }^{21}$ Insofar as it is limited to the district court level, such an attack may, however, be restricted in effectiveness to temporary postponement of the judicial response.22 Even if southern politicians are able to secure appointment of judges at the district level whose political interests are identical to those of dominant state legislative interests, the task of controlling, through the appointive process, the responses at the circuit court and Supreme Court level is far more difficult. In any case, the infrequency of judicial appointments renders this an inherently long term approach to the problem. In the interests of a short term, more effective "remedy," the states have continued a search for other techniques that might preclude a suit challenging the social fabric from being instituted in the first instance.

19. For discussions of these and other forms of attack directed at the NAACP see Aarerican Jewish Congress, Assault Ufon Freedoas of Assoctation-A Study of tHe Southern Attack on the National Association for the Advancesent of Colored People (1957); Robison, Protection of Associations from Compulsory Diselosure of Membership, 58 Colusr. L. Rev. 614 (1958); Mirphy, The South Countcrallacks: The Anti-NAACP Lazes, 12 W. PoL. Q. 371 (1959).

20. See NAACP v. Alabama ex rel. Patterson, 357 U.S. 449 (1958); Bates v. Little Rock, 361 U.S. 516 (1960); Shelton v. Tucker, 364 U.S. 479 (1960), revcrsing Shelton v. McKinley, 174 F. Supp. 351 (E.D. Ark. 1959) ; and Gibson v. Florida Legislative Investigation Committee, 372 U.S. 539 (1963).

21. Several of President Kennedy's appointments in the Fifth Judicial Circuit seem clearly within this category. See Bickel, Civil Rights, The New Republic, Vol. 147, No. 24, Issue 2508, December 15, 1962, pp. 11, 16; and Bickel, Civil Rights Boil-Up, The New Republic, Vol. 148, No. 23, Issue 2533, June 8, 1963, pp. 10, 11-12. It might be argued that the traditional veto power held by senators over judicial appointments in their districts rather than direct pressure upon the President has resulted in these appointments. But, even granted that tradition is unbreakable in this area, the President retains the power to make no appointment and to allow the Chief Justice to assign a judge from another district to fill any vacancy. $I d$. at 12 .

22. The device remains extremely effective, however. As Professor Bickel noted:

This is a matter of first importance, now and in the future, for district judges have life tenure, of course, they ordinarily sit alone, and they have much discretionary power which is not easily subject to review by the Court of Appeals, nor the Supreme Court.

Bickel, Civil Rights, note 21 supra at 16. 
The framework for such an attack lay in existing state legislation regulating the conduct of the legal profession. Prior to 1956, Virginia's regulations, typical of those in most states, controlled solicitation of business for an attorney. It rendered his agent subject to prosecution for a misdemeanor ;3 the attorney who advertised or solicited business directly or indirectly was subject to disbarment. ${ }^{24}$ In addition to this statutory identification of unprofessional conduct, the practice of law was controlled by the Canons of Legal Ethics formulated by the American Bar Association, and adopted by the Virginia Supreme Court of Appeals. ${ }^{25}$ Thus, though barratry- "stirring up strife and litigation" - was not specifically prohibited by statute, it was a cause for dis. barment under Canon 28. ${ }^{26}$ Maintenance, wrongfully intermeddling in a suit through financial or other types of assistance, was also regulated only through application of the canons. Under Canon 42, attorneys were prohibited from pay. ing the out-of-pocket expenses of their clients' lawsuits. ${ }^{27}$ In addition to the regulations directed at lawyers, pre-1956 Virginia statutes also attempted to govern the participation of organizations in the practice of law. Rendering legal services by non-lawyers and corporations employing lawyers for that purpose was made illegal ;8 $^{28}$ moreover, control of an attorney by a lay intermediary was a sufficient basis for the lawyer's discipline under Canon 35.20 And under Canon 47 disciplinary action could be taken if the attorney aided or abetted an

23. Va. Acts 1932, ch. 284, at 512-13 (now VA. CoDE ANs. \$§ 54-78, 54-79 [1958 Replacement]).

24. Va. Acts 1932, ch. 129, at 138 (now VA. Code ANN. \$ 54-74 [1958 Replacement]).

25. $171 \mathrm{Va}$. xviii-xxxv (1938). The first code of legal ethics was adopted by the Alabama State Bar Association in 1887. DrINKER, LEGAl ETHICs 23 (1953). This was followed in 1908 by the adoption of the Canons of Professional Ethics by the American Bar Association. Id. at 24. Since 1908, most state bar associations have adopted the American Bar Association code. National amendments are either carried over automatically or specially inserted in the state codes; thus, the provisions of the Canons are fairly uniform nationwide. Id. at 25. As a general rule, the Canons do not have the force of law. They are commonly used by the courts, however, in disciplining attorneys, as standards for determining proper professional conduct. Id. at 26-30. But the Virginia Canons of Professional Ethics wero adopted by the Virginia Supreme Court of Appeals pursuant to VA. CoDE ANN. § 54-48 (1958 Replacement) and thus have the force and effect of law.

26. Canon 28 provides in part:

It is unprofessional for a lawyer to volunteer advice to bring a lawsuit, except in rare cases where ties of blood, relationship or trust make it his duty to do so. . . . It is disreputable to hunt up defects in titles or other causes of action and inform thercof in order to be employed to bring suit or collect judgment, or to breed litigation by seeking out those with claims for personal injuries or those having any other grounds of action in order to secure them as clients, or to employ agents or runners for like purposes....

171 Va. $x x i x-x x x(1938)$.

27. 171 Va. xxxiv (1938).

28. VA. Code ANN. \$ 54-44 (1958 Replacement); Richmond Ass'n of Credit Men, Inc. v. Bar Ass'n, 167 Va. 327, 189 S.E. 153 (1937).

29. Canon 35 provides in part:

Intermediaries.-The professional services of a lawyer should not be controlled or exploited by any lay agency, personal or corporate, which intervenes between client 
organization engaged in the unauthorized practice of law. ${ }^{30}$ But champerty, barratry, and maintenance were traditionally conceived as directed at commercial evils and, hence, not applied to gratuitous offering of legal services. ${ }^{31}$ There had never been a successful attempt, prior to 1956, to apply them to organizations such as the NAACP or the Legal Defense Fund or to find those charitable organizations engaged in the unauthorized practice of law.

Because of these difficulties, it was widely felt in the South that the existing legislation would not serve effectively as an attack on NAACP ability to litigate. Virginia became the second of seven southern states to enact legislation broadening former definitions of barratry, maintenance, and solicitation to include the activities of the NAACP, the Fund, and their attorneys. ${ }^{32}$ In its 1956 Extra Session, the Virginia Assembly enacted Chapter 35 of the Virginia laws, defining barratry to include any arrangement where persons having no direct or pecuniary interest contribute toward the expenses of a lawsuit, whether or not such a contribution resulted in "stirring up" undesirable litigation. ${ }^{33}$ Chapter 36 , expanding the meaning of maintenance, made it unlawful to give or receive money, goods, or services as an inducement to the institution of a suit against the government, or advocate such a suit, regardless of motive. $^{34}$ The language of these broadened definitions was qualified only by exempting contingent fee contracts, certain kinds of zoning and title-quieting pro-

and lawyer.... A lawyer's relation to his client should be personal, and the responsibility should be direct to the client...

A lawyer may accept employment from any organization, such as an association, club or trade organization, to render legal services in any matter in which the organization, as an entity, is interested, but this employment should not include the rendering of legal services to the members of such an organization in respect to their individual affairs.

171 Va. xxxii-iii (1938).

30. Canon 47 provides:

Aiding the Unauthorized Practice of Lazu.-No lawyer shall permit his professional services, or his name, to be used in aid of, or to make possible, the unauthorized practice of law by any lay agency, personal or corporate.

$171 \mathrm{Va} . \operatorname{xxxv}(1938)$. All states have provisions restricting entry into the legal profession and barring unlicensed persons from the practice of law. Under these provisions it is generally agreed that corporations may not practice law. (Recently a number of states have passed statutes enabling law firms to "incorporate" for federal tax purposes. Firms incorporated under these statutes, however, possess few of the normal incidents of a corporate form. See Bittker, Professional Associations and Federal Income Taxation, 17 TAx L. REv. 1 (1961) and 5 Countryaran, The Lawyer In ModerN SOciety 258-82 (1962).)

31. See note 75 infra.

32. The legislation in the other six states is similar to Virginia's. See ARK. Stat. Awz. $\S \S 41-703$ to -713 (Supp. 1961) (added in 1958); FLA. STAT. Aws. \$§ 877.01 to 877.02 (Supp. 1962) (added in 1959) ; GA. CoDE ANN. \$ 26-4701 to -4703 (Supp. 1961) (added in 1960 to replace similar legislation enacted in 1957); Mrss. CoDE ANN. \$\$ 2049-01 to -0S (1956) (added in 1956) ; S.C. Cope ANN. \& 16-521 to -525 (1962) (added in 1956); and TENN. Code ANN. \$§ 39-3405 to -3410 (Supp. 1962) (amended in 1957).

33. VA. CODE ANN. $\S \S 18.1-388$ to -393 (1960 Replacement).

34. VA. CODE ANN. $\$ \S 18.1-394$ to -400 (1960 Replacement). 
ceedings, and payments to attorneys by approved legal aid societies. ${ }^{85}$ Chapter 33 seemed to expand the definition of "running and capping" and "unprofessional conduct" to include conduct largely resembling the regular behavior of the NAACP. ${ }^{36}$ Running and capping now explicitly included the procurement of legal business for a corporation which compensates attorneys serving in judicial proceedings where the corporation has no direct interest, regardless of the charitable character of the corporation or the fact that litigants do not contribute to the costs of litigation. ${ }^{37}$ And unprofessional conduct was broad-

35. VA. CODE ANN. $§ 18.1$ - 388(f), 18.1 - 399 (1960 Replacement).

36. Chapter 33 amended and reenacted VA. CoDE ANN. $\S \S 54-74,54-78,54-79$ (1958 Replacement). Section $54-74$ provides in part:

(1) Issuance of ralle.-If . . any court of record of this State, observes, or if complaint, verified by affidavit, be made by any person to such court of any malpractice or of any unlawful or dishonest or unworthy or corrupt or unprofessional conduct on the part of any attorney ... such court shall, if it deems the case a proper one for such action, issue a rule against such attorney ... to show cause why his license to practice shall not be revoked or suspended.

$$
\neq * *
$$

(4). Action of court.-Upon the hearing, if the defendant be found guilty by the court, his license to practice law ... shall be revoked, or suspended for such time as the court may prescribe; provided, that the court, in lieu of revocation or suspension, may, in its discretion, reprimand such attorney.

(6) "Any malpractice, or any unlazuful or dishonest or unworthy or corrupt or umprofessional conduct", as used in this section, shall be construed to include the improper solicitation of any legal or professional business or employment, either directly or indirectly, or the acceptance of employment, retainer, compensation or cosis from any person, partnership, corporation, organization or association zuith knowledge that such person, partnership, corporation, organization or association has violated any provision of article 7 of this chapter [\$\$ 54-78 to -83.1] .... [Italics added to show amended parts].

Section $54-78$ provides in part:

(1) A "runner" or "capper" is any person, corporation, partnership or association acting in any manner or in any capacity as an agent for an attorney at law within this State or for any person, partnership, corporation, organization or association which employs, retains or compensates any attorney at law in connection with any judicial proceeding in which such person, partitership, corporation, organization or association is not a party and in which it has no pectmiary right or liability, in the solicitation or procurement of business for such attorney at law or for stich person, partnership, corporation, organization or association in connection with any judicial proceedings for which sich attorney or stch person, partnership, corporation, organization or association is employed, retained or compensated.

$$
* * *
$$

(2) An "agent" is one who represents another in dealings with a third person or persons. [Italics added to show amended parts].

Section 54-79 provides in part:

It shall be unlawful for any person, corporation, partnership or association to act as a runner or capper as defined in \$ 54-78 to solicit any business for alt allorincy at law or such person, partnership, corporation, organization or association . . . . [Italics added to show amended parts].

37. VA. Code ANN. § 54-78 (1958 Replacement). 
ened to include an attorney's acceptance of compensation from anyone guilty of running and capping. ${ }^{38}$

The crippling effect this legislation would have had on the NAACP if enforced was clear from the outset, given the structure of the Association's activities at the state level. ${ }^{39}$ In Virginia, the NAACP's 89 local branches were organized into the Virginia Conference. ${ }^{40}$ Both the branches and the Conference, through public meetings, encourage Negroes to assert their rights against the state; this action was certain to fall within the amended definition of maintenance. ${ }^{41}$ Moreover, the added inducement of Association willingness to provide

38. VA. CODE ANN. § 54-74 (6) (1958 Replacement). Supplementing Chapters 33, 35, and 36 were Chapter 31, VA. CoDE ANN. $\S \S 18.1-372$ to -379 (1960), requiring persons or organizations soliciting or expending money in connection with litigation to register the names and addresses of members, officers, employees, and contributors, as well as detailed financial statements and a certified copy of the organization's charter; Chapter 32, VA. CodE ANN. $\$ \S 18.1-380$ to -387 (1960), requiring that the same information demanded in Chapter 31 , supra, be given by any person or organization active in

promoting or opposing in any manner the passage of legislation by the General Assembly in behalf of any race or color, or who or which has as one of its principal functions or activities the advocating of racial integration or segregation or whose activities cause or tend to cause racial conflicts or violence, or who or which is engaged or engages in raising or expending funds for the employment of counsel or payment of costs in connection with litigation in behalf of any race or color, in this State [,]

VA. CODE ANn. § 18.1-381 (1960) ; and Chapters 34 and 37, Va. Acts 1956 Ex. Sess., chs. 34,37 , setting up legislative committees to oversee the enforcement of the various provisions and to investigate and hold hearings to determine whether any additional legislation was needed.

39. The promotion of litigation eventually sponsored by the Association or the Fund is carried on at the local level by NAACP branches, other Negro rights organizations, and the Negro bar. In Virginia the NAACP has a membership of approximately 13,500. NAACP v. Button, 371 U.S. 415, 419 (1963). The Virginia Conference of NAACP Branches maintains a legal staff of fifteen members and sponsors litigation independently of both the national office and the Fund f for this purpose it spent more than $\$ 25,000$ in a twoyear period between 1956 and 1958. Ibid.; Record No. 5096, pp. 281-86, NAACP v. Harrison, 202 Va. 142, 116 S.E. $2 d 55$ (1960). Although members of the legal staff generally maintain private practices, a large part of their time is spent in Conierence activities, for which they receive expense reimbursement and per diem compensation when involved in sponsored litigation. NAACP v. Harrison, 202 Va. 142, 149, 116 S.E. 2d 55, 62 (1960). In their respective communities, members keep alert for and prosecute Conference-sponsored suits. Occasionally they address groups of Negroes to inform them of or to encourage them to assert their constitutional rights. Collectively they exchange ideas and map out strategies relative to suits sponsored by the Conference and involving common issues.

Suits arise in a number of different ways. See NAACP v. Button, stopra at 421-22; and NAACP v. Harrison, supra at 147-51, 116 S.E. 2d at 60-63. Certain kinds of suits begin with a request by an individual for NAACP assistance. Litigants either go directly or are referred by a branch official to a member of the Conference legal staff. If the chairman of the staff and the president of the Conference concur, the Conference will agree to defray some of the expenses of litigation. Often, additional assistance is sought from the Fund. In school litigation, which since 1954 has constituted the major part of the Conference's legal work, the procedure is more complex. See note 43 infra.

40. NAACP v. Button, 371 U.S. 415,419 (1963).

41. VA. Code ANn. § 18.1-394 (1960 Replacement). 
legal assistance, would constitute both maintenance and barratry. ${ }^{42}$ Often, at the instance of the local NAACP branch, a church or other social group, Conference officials or members of the legal staff addressed school parents, explained the legal procedures for challenging segregated schools, and urged them to act. At some of these meetings prepared forms were distributed at1thorizing staff lawyers to institute suit on behalf of the person signing.43 These authorizations, and the common practice of directing inquiries to the Conference for legal action when prospective litigants approach branch members directly, would seem to satisfy the requirements of solicitation under the 1956 laws. ${ }^{44}$

\section{The Judiciai Response: Police Power v. Free Speech}

In 1957 the NAACP and the Fund instituted declaratory judgment proceedings in a three-judge federal district court, seeking to have the entire statutory establishment declared unconstitutional insofar as it might apply to them. After a complicated course of litigation, they succeeded in obtaining from the Virginia courts a declaration that all of the acts except Chapter 33 [solicitation] were unconstitutional, on the ground that they interfered with freedom of association, with the first amendment right to advocate pursuit of legal rights through litigation, and with a due process right of access to courts which includes the rights to finance and receive assistance for litigation. ${ }^{45}$ But while affirming the right of the NAACP and the Fund to advocate and finance litiga-

42. VA. CodE ANN. §§ 18.1-388, 18.1-394 (1960 Replacement).

43. Often, as many as 150 persons are joined as plaintiffs in a school suit. See NAACP v. Button, 371 U.S. 415,422 n. 6 (1963). Once a suit is instituted, the staff lawyer in charge often brings in other members of the staff. In addition, especially at appellate levels, Fund assistance may be sought.

44. VA. CODE ANN. \& 54-78 (1958 Replacement).

45. The NAACP and the Fund first sought a declaratory judgment and an injunction enjoining the enforcement of Chapters $31,32,33,35$ and 36 (see notes 33-38 supra and accompanying text) in the federal district court. The three judge court in NAACP v. Patty, 159 F. Supp. 503 (E.D. Va. 1958), held Chapters 31,32 and 35 unconstitutional but with" held judgment on Chapters 33 and 36 pending a state court construction. This holding was reversed by the Supreme Court in Harrison v. NAACP, 360 U.S. 167 (1959), on the ground that a prior state construction of all the chapters was necessary. After the decision in Patty, resort was had to the state court with respect to Chapters 33 and 36, the NAACP asking for a construction and an injunction against enforcement and the Fund asking for a construction only. The suits were consolidated and the Virginia Supreme Court of Appeals in NAACP v. Harrison, 202 Va. 142, 116 S.E.2d 55 (1960), construed both chapters to prohibit certain activities of both the NAACP and the Fund. The court proceeded to declare Chapter 36 but not Chapter 33 unconstitutional. At this point the N.A.A.C.P. and the Fund parted company, the NAACP seeking certiorari with respect to that part of the opinion upholding the constitutionality of Chapter 33 and the Fund returning to the district court with its construction. The NAACP's suit culminated in NAACP v. Button, 371 U.S. 415 (1963). In the meanwhile, after the decision in Harrison v. NAACP, sitpra, the NAACP and the Fund initiated state proceedings with respect to Chapters 31,32 , and 35 . Before the Circuit Court of the City of Richmond the state conceded the unconstitutionality of Chapter 35 under NAACP v. Harrison, stupra. The court proceeded to hold unconstitutional not only Chapter 35, but also Chapter 31 and the principal provisions of Chapter 32. NAACP Legal Defense 
tion, the Virginia court condemned their practices of soliciting litigation for and making payments to their own attorneys or other particular attorneys, finding such practices both legally prohibited and constitutionally prohibitable by Chapter $33 .{ }^{46}$ The court rejected an argument, made improbable by the recent legislative expansion of the definition, that NAACP activities did not come within the meaning of solicitation. In fact, it suggested that these activities were so far within the traditional doctrines of solicitation as also to violate pre-1956 strictures against unauthorized practice and the intervention of lay intermediaries. As the court characterized the Association's activities, they included not only vigorous advocacy and generous financing of litigation carefully channeled to particular lawyers, but also substantial elements of control over the day-to-day management of litigation. ${ }^{47}$ It seems, however, that the court made these findings of control not to satisfy a construction of statutory language but to demonstrate $a$ fortiori that the organizations fell within language "clear and definite in ... [its] meaning." 18 What the court felt to be the boundaries of "solicitation" were left undefined beyond common understanding, except, perhaps, to the extent that in a subsequent part of the opinion the court suggested limitations by its exclusion of unchannelled financing and advocacy, activity which it said fell within the protection of the first and fourteenth amendments. ${ }^{49}$

On certiorari, the United States Supreme Court reversed.00 The majority found the Virginia court's attempted distinction between non-directed advocacy and "channeling" insufficient to counterbalance readily predictable infringements on admitted speech activity; it held the statute as construed to be an unconstitutional impairment of freedom of speech. Referring to the need to regulate the areas bordering speech with "narrow specificity," the Virginia court to proscribe "any arrangement by which prospective litigants are advised to seek the assistance of particular attorneys." that a criminal violation might arise from "simple referral"w3 was said to give

and Educational Fund, Inc v. Harrison, Ch. No. B-2879, Cir. Ct. City of Richmond, Va, Aug. 31, 1962; NAACP v. Harrison, Ch. No. B-2880, Cir. Ct. City of Richmond, Va., Aug. $31,1962$.

46. NAACP v. Harrison, 202 Va. 142, 164-65, 116 S.E. $2 d$ 55, 72 (1960).

47. Id. at 150, 155, 116 S.E.2d at 62, 65-66. In finding that the NAACP controlled sponsored litigation, the court relied heavily on the Association's policy, adopted in 1950, of not financing school suits seeking separate but equal facilities. Id. at 149, 116 S.E. $2 d$ at 62 . The court viewed evidence that certain plaintiffs in NAACP sponsored suits had had no contact with their attorneys and in some cases had been unaware that suits had been instituted in their names as further proof of control by the Association. Id. at 150-51, 155, 116 S.E. 2 d at 63, 65-66. It concluded that both litigants and attorneys "must adhere to a policy of permitting the NAACP, the Conference and the Fund to direct and control the litigation." Id. at 155,116 S.E. $2 \mathrm{~d}$ at 65 .

48. Id. at 154,116 S.E. $2 \mathrm{~d}$ at 65 .

49. Id. at 163-65, 116 S.E. 2d at 71-72.

50. NAACP v. Button, 371 U.S. 415 (1963).

51. Id. at 433 (1963).

52. Ibid.

53. Ibid. 
rise to "the gravest danger of smothering all discussion looking to the eventual institution of litigation on behalf of the rights of members of an unpopular minority." The breadth and vagueness of the statute, enabling excessive prosecutorial discretion, might lead to such inhibition of the concededly protected forms of expression as to prohibit them. This was especially true for the NAACP, since it was doubtful that it could effectively utilize the protected rights to advocate and finance litigation in the context of a largely hostile southern bar without appearing to channel to particular attorneys. ${ }^{\text {to }}$ Thus, the Court, though admitting that channeling of litigants to particular attorneys was non-speech in first amendment terms, ${ }^{56}$ found the Association's acts so intimately connected with protected action as to deprive first amendment freedoms of needed "breathing space."57

If the Court had merely struck the statute on these grounds of vagueness, its action might have been no more than an invitation for more careful drafts.

54. Id. at 434.

55. The dissenters did not question the majority's prediction that a statute prohibiting "simple referral" might effectively prohibit or discourage advocacy and financing. Instead, they challenged the majority's finding that Chapter 33 was such a statute. To them, it seemed clear that Chapter 33 required not only referral but also payment and control of the lawyer to whom a litigant is referred. NAACP v. Button, 371 U.S. 415, 466-68 (1963) (dissenting opinion). Alternatively, they argued that Chapter 33 was separable-that the Court might have struck the statute insofar as it applied to bar "simple referral" and yet have left intact its application to activities such as those of the NAACP which the Virginia court had found to include both control and referral. Id. at 468-69.

56. This is not to say that the Court held "channeling" (referring litigants to particular attorneys) wholly without the area of constitutional protection. Other parts of its opinion would indicate the contrary. See note 61 infra and accompanying text. For purposes of its void-for-vagueness discussion, however, the constitutional status of "channeling" was irrelevant. The basis of the Court's argument was that even if a state might prohibit "channcling," it could not do so in such a manner as also to prohibit or discourage advocacy and financing-activity which was admittedly protected.

57. The Court's holding that Chapter 33 was "void-for-vagueness" seems to have been grounded upon the difficulty, given advocacy and financing, of disproving referral. Because of this difficulty, the Court feared that a prohibition of "simple referral" would deter persons from advocating and financing litigation and thus giving the appearance of having referred. By basing its decision on such considerations, the Court may have extended the former contours of the void-for-vagueness doctrine. For Button is neither of the class of cascs typified by Lanzetta v. New Jersey, 306 U.S. 451 (1939), "in which a legislature which might constitutionally have proscribed either or both of two classes of behavior, $A$ and $B$, has chosen to proscribe only $A$, but in language so uncertain that whether most fact situations are $A$ or $B$ is a matter for guesswork," Note, The Void-for-Vaguencss Doctrine in the Supreme Court, 109 U. PA. L. Rev. 67, 76 (1960), nor of the class typified by Winters v. New York, 333 U.S. 507 (1948), "in which a legislature, constitutionally free to regulate sphere $A$, but forbidden to encroach upon sphere $B$, has included indiscriminately within the broad wording of a criminal statute both $A$ cases and $B$ cases, thereby leaving the individual to guess at his peril whether he can or cannot be constitutionally punished for violation of the statute," ibid. While Button is kindred to the latter class of cases, it is different in that Chapter 33 did not in terms prohibit "sphere $B$ " conduct. Nor was there any ambiguity in this respect. Only referral was prohibited; the right to engage in "sphere $B$ " conduct-advocacy and financing-was specifically affirmed. 
manship by the Virginia legislature, since its opinion would have posed no bar to regulations requiring further elements of control. In fact, the form for such redefinition was readily available in those Canons of Legal Ethics respecting unauthorized practice which the Virginia court had asserted to be applicable to the activities in question." Such new prohibitions, based on the "lay intermediary" character of the Association's activities, would compel disbanding the Virginia legal staff. As a result, the planning and tactical advantages to be gained through coordination of select groups of expert, interested lawyers would be unavailable. And since professional careers would hang upon adjudication of alleged violations before expectably biased juries, a control test would probably increase NAACP dissociation from litigation to a degree beyond that appearing from its terms. ${ }^{59}$ To avoid this result, the majority opinion

58. The Virginia court held that lawyers for the NAACP and the NAACP Legal Defense and Educational Fund were violating Canons 35 and 47 of the Virginiz Canons of Professional Ethics. NAACP v. Harrison, 202 Va. 142, 156, 164, 116 S.E.2d 55, 67, 72 (1960). Canon 35 on lay intermediaries and Canon 47 on the unauthorized practice of law are both directed at elements of control in organizational activity. See notes 29-30 supra. By finding Association and Fund lawyers in violation of Canon 47, the court impliedly found both organizations to be engaged in the unauthorized practice of law. Thus, if the Supreme Court had limited itself to a holding that any statute barring "simple referral" is void-for-vagueness, Canons 35 and 47 and the Virginia unauthorized practice statute (see note 28 sipra) would have remained in force to prohibit the organization's activities.

59. Justice Harlan read Chapter 33 as prohibiting referral to lawyers controlled by the Association. NAACP v. Button, 371 U.S. 415, 466-68 (dissenting opinion). So construed he did not believe the statute would substantially impair the Association's effectiveness. Id. at 465 (dissenting opinion). The correctness of this prediction would depend in part upon the content later given the concept of "control." If employment or membership on a legal staff such as that of the Virginia Conference (see note 39 supra) were adopted as the sine qua non of control, the Association and the Defense Fund would have been greatly inconvenienced but not disabled. The Conference would have had to disband its staff and the Defense Fund would have had to fire its attorneys and break up its office. Mlany strategic and tactical advantages would thus have been sacrificed, but both would have been able to continue advocating and financing litigation.

The decree of the Virginia Supreme Court of Appeals, however, shows that it would have given "control" a much wider content. There are indications, for example, that the court would have required that attorneys be paid by the litigants themselves and that any assistance given litigants be in the form of cash without strings as to the manner of prosecuting or the attorney to prosecute the suit. It seems certain, moreover, that the court would not have been satisfied with a mere disbanding of the legal staff. Any former association or present working relationship with the Conference or the Defense Fund would have been considered strong evidence of control. Thus, for example, attorneys to whom litigants were regularly referred might have been deemed "controlled" by the Conference, regardless of the fact that they were compensated by the litigants directly, because of the attorneys' possible reliance on this source of business. (Under the interpretation of the Virginia decree adopted by the majority, of course, such referral would have been unlawful per se.)

Had such a content been given the concept of control, large numbers of difficult factual questions would have been made available for manipulation by possibily biased juries. ( $E$.g., Did the litigant receive the money without strings or was there a stipulation that the suit be for integrated and not merely separate but equal facilities? In determining whether to grant assistance, does the Conference or the Defense Fund consider the personality of the lawyer selected by the litigant?) Since the right to practice law of every lawyer handling 
went beyond the issue of the constitutionality of the statute as construed, to an exploration of the constitutionality of the application to the NAACP or, impliedly, other civil rights litigators, of the usual forms of regulation of legal practice, despite the normal practice of limiting constitutional decision to matters necessarily before the Court.

To sweep such hypothetical regulations within its disapprobation, the majority opinion of Justice Brennan employed expanded concepts of speech and association and unusually restrictive attitudes toward state regulatory powers. While the infirmities of Chapter 33 as construed are discussed in terms of "real" speech-acquainting persons with their legal rights, advising them to institute litigation, etc.-where the Court turns to a discussion of NAACP activities it ignores lines of distinction between the rights of free speech, assembly, and petition. ${ }^{60}$ In place of such distinctions, the Court demonstrates a functional concern with the need for free political expression as the basis for the unimpeded operation of the democratic process. ${ }^{01}$ NAACP activities, which the Court found presented only a "superficial resemblance in form"02 to traditionally defined improper practices, were thus found to be within the meaning of the first amendment regardless of whether they constituted "solicitation." Consequently, the generalized danger which usually serves to justify state

sponsored litigation would have hinged upon the resolution of such questions (which resolution, incidentally, could not effectively have been reviewed on appeal by the Supreme Court), there would seem to be much truth in the prediction of disaster made by the Association's General Counsel:

[F] ar more devastating than any specific limitation on our activity, which would have resulted from the state decision being upheld, would have been the climate created in Virginia and throughout the South. Lawyers, particularly those accustomed to working in this area, would have had to be gravely concerned about their professional careers. I doubt if we could have secured local lawyers to carry on civil rights litigation. Indeed, in my judgment, affirmation of the state decision would have been as effective a destruction of the NAACP as anything which could have been devised.

Letter from Robert I. Carter, General Counsel of the National Association for the Advancement of Colored People, to the Yale Law Journal, April 15, 1963, on file in Yale Law Library.

60. Compare NAACP v. Button, 371 U.S. 415, 429-31 (1963), with id. at 431-34.

61. The Court held that the activities of the Association revealed by the record werc, in toto, "modes of expression and association protected by the First and Fourtcenth Amendments." Id. at 428-29. Thus, first amendment protection was not limited to such speech activity as acquainting persons with their legal rights and urging them to institute suits; it was extended to include all incidents to political litigation activitics by associtwtions. In thus augmenting the growing block of associational rights, the Court recognized the political character and importance of group litigation.

In the context of NAACP objectives, litigation is not a technique of resolving private differences; it is a means for achieving the lawful objectives of equality of treatment by all government, federal, state and local, for the members of the Negro community in this country. It is thus a form of political expression.... [U]nder the conditions of modern government, litigation may well be the sole practicable avenue open to a minority to petition for redress of grievances.

$I d$. at 429-30. Cf. Thomas v. Collins, 323 U.S. 516 (1945).

62. 371 U.S. at 442. 
regulatory measures, even where they extend for reasons of administrative convenience into areas where the danger may fairly be said not to exist, would be insufficient to justify statutory regulation of civil rights litigators. Only where specific and compelling dangers rise from the practices themselves may the NAACP's litigating practices be regulated, in view of the added compulsion of first amendment considerations to non-regulation. ${ }^{03}$ Although couched in specific terms of NAACP litigating activities, these portions of the opinion were clearly marked by the Court as applicable to similar regulation of any of the civil rights litigating groups. ${ }^{64}$

Four members of the Court dissented from this expansive approach to associational rights. Although Mr. Justice Harlan, with Justices Clark and Stewart concurring, dissented also from the "void for vagueness" finding of the Court, it was the associational problem to which he gave his most serious attention. ${ }^{\text {as }}$ Mr. Justice White, who concurred in the Court's application of first amendment principles to the statute as construed, reacted strongly to what he termed the decision of "a case not before the Court," have been more willing to sustain regulation which required proof of actual control of the day-to-day course of litigation by the NAACP.07 Mr. Justice Harlan agreed that litigation such as the NAACP engaged in was a form of expression within the first amendment ;8 but, relying principally on the possible dangers of conflicts of interest between the NAACP and sponsored litigants, "precipitate resort to litigation,"69 and "unnecessarily broad attacks based upon inadequate records," he argued that on balance Virginia's regulation was reasonable and fully supported by the state's "interest ... [in] maintaining high professional standards among those who practice law within its borders."71

63. The Court clearly implied that it would require a showing of something on the order of "neglect or harassment of clients" or "injurious intervention in or control of litigation" before it would consider regulation of the NAACP's litigating activities justified. Id. at 433, 444.

64. Id. at 444.

65. Id. at 448-470 (dissenting opinion).

66. Id. at 448 (concurring opinion of Justice White).

67. Id. at 447-48 (concurring opinion of Justice White). In thus reiusing to extend a blanket approval to the NAACP's activities, Justice White took the middle position between Justices Brennan and Harlan. Distinguishing "actual control" from "control" as defined by the Virginia court, he found only the latter protected. Although "actual control" is nowhere precisely defined, it clearly means something more than "advising Negroes of their constitutional rights, urging them to institute litigation of a particular kind, recommending particular lawyers and financing such litigation" (id.at 447) and something less than the "injurious intervention in or control of litigation" (id. at 444) required by the majority. Justice White carefully avoided deciding whether the existence of an employment or official relationship between attorneys and the sponsoring organization would constitute "actual control."

68. Id. at $452-53$ (dissenting opinion).

69. Id. at 464 (dissenting opinion).

70. Ibid.

71. Id. at 455 (dissenting opinion). Neither the majority opinion of Justice Brennan, the concurring opinion of Justice White, nor the dissenting opinion of Justice Harlan devoted 
Mr. Justice Harlan's dissent draws its strongest support from state interests in regulating the practice of law-interests which surpass the usual regulatory interest in protecting unknowing consumers of goods and services from hardto-identify incompetents and frauds. Here, the state must also protect both a relationship requiring an atmosphere of utmost trust, and the operation of its courts, an essential part of its functional governing machinery. As Mr. Justice Harlan noted in Cohen v. Hurley:

It is no less true than trite that lawyers must operate in a three-fold capacity, as self-employed businessmen as it were, as trusted agents of their clients, and as assistants to the court in search of a just solution to dis. putes. It is certainly not beyond the realm of permissible state concerns to conclude that too much attention to the business of getting clients may be incompatible with a sufficient devotion to duties which a lawyer owes to the court, or that the "payment of awards to persons bringing in legal business" is inconsistent with the personally disinterested position a lawyer should maintain. ${ }^{\mathbf{2}}$

The Supreme Court, moreover, has generally been tolerant in dealing with both the legislative choice and the application of regulations conceded to be within these interests, even where the application is to situations arguably not within their rationale. ${ }^{73}$ This tolerance has frequently been justified by the need to recognize state choice of administratively convenient means to reach legitimate ends and the desire to abstain from deciding cases on the basis of the wisdom or purpose of state legislation where the usual application appears justified. ${ }^{74}$ If organizational litigators present substantial dangers (either of

any attention to the politically responsive aspects of the statute's passage. The vaguencss of the Virginia statute aside, it seems that all the opinions except Justice Douglas' short concurrence (371 U.S. at 445-46) viewed the problem of striking state regulatory statutes governing politically expressive litigation as a first amendment balancing problem. Asserting that the Virginia legislation reflected "a legislative purpose to penalize the NAACP because it promotes desegregation of the races" (371 U.S. at 445) and "was part of the program of 'massive resistance' against Brown v. Board of Education, [347 U.S. 483 (1954) ]" (371 U.S. at 446), however, Justice Douglas argued that the legislation was also objectionable on equal protection grounds. While this approach might be criticized as involving judicial inquiry into legislative "motive" [see, e.g., Howell, Legislative Motive and Legislative Purpose in the Invalidation of a Civil Rights Statute, 47 VA. L. REv. 439 (1961), criticizing use of this approach by Judge Soper in the related case of NAACP v. Patty, 159 F. Supp. 503 (E.D. Va. 1958) ], it draws strong support from such cases as Cooper v. Aaron, 358 U.S. 1 (1958), where the Court has made clear that it will not tolerate "cvasive schemes for segregation whether attempted "ingeniously or ingenuously" " (id. at 17).

72. Cohen v. Hurley, 366 U.S. 117, 124 (1961).

73. In Martin v. Walton, 368 U.S. 25 (1961), for example, the Court dismissed "for want of a substantial federal question" an appeal challenging the constitutionality on cequal protection grounds of Kansas court rules barring attorneys regularly practicing in other states from appearing in Kansas courts without associating local counsel, as applicd to a member of the Kansas and Missouri bars who regularly practiced in both states, despite the dissent's apparently correct assertion that the declared regulatory interests had no bearing upon the particular result achieved. Such attorneys zould be conveniently available for the service of Kansas process and would have the requisite knowledge of local procedure.

74. See, e.g., Ferguson v. Skrupa, 372 U.S. 726, 728-32 (1963); Williamson v. Lee 
the kind against which traditional prohibitions of solicitation and unauthorized practice are directed or of a kind which might justify an extension of such prohibitions) —and Justice Harlan's argument that they do is persuasive-or if the activities of these litigators are so like others which do present dangers that it would be difficult if not impossible effectively to prohibit one without prohibiting the other, those parts of the majority opinion which go beyond a finding that Chapter 33 was void for vagueness may be seriously questioned.

In asserting that traditional doctrines of solicitation and unauthorized practice have no application to the activities of organizational litigators, the majority was on safe ground. ${ }^{75} \mathrm{It}$ is in commercial contexts that the evils with which

Optical, Inc., 348 U.S. 483, 487-91 (1955) ; Olsen v. Nebraska ex rel. Western Reference \& Bond Ass'n, 313 U.S. 236, 246-47 (1941).

75. That these doctrines have no relevance to such activities appears primarily from the history of their development and the nature of the evils at which they are directed. Rules against solicitation developed in the genteel atmosphere of the early English bar, to protect its fraternal intimacy from destruction by competitive strife. DrRnkER, LeGal. ETHICs 210 (1953). While solicitation rules rest on a broader basis today, the continuing desire to prevent commercialization of the profession is primarily responsible for their present vitality. In addition, it is feared that solicitation would promote unnecessary and possibly fraudulent litigation and would encourage attorneys to make extravagant and misleading claims as to their ability and the strength of their clients' cases. See generally Note, $A$ Crilical Analysis of Rules Against Solicitation by Lawyers, 25 U. CHL. L. Rev. 674 (1958).

In view of these purposes, solicitation rules have been held inapplicable to offers of gratuitous assistance not made in a commercial context. See In re Ades, 6 F. Supp. 467, 480-81 (D.C. Md. 1934) (lawyer for International Labor Defense voluntecred to assist Negro charged with murder of white family); Gunnels v. Atlanta Bar Ass'n, 191 Ga. 366, 373,12 S.E.2d 602, 610 (1940) (local bar association offered lenders free legal assistance in campaign to suppress usurious loan companies); Aarerican BAr Assocution, supra, Opinion 148 (1935), at 308 (committee of American Liberty League which believed the Wagner Act to be unconstitutional offered to defend without charge any person affected thereby.) But see Comartrtee on Professional Ethics of tme New Yonk Counity LAwYERs' Association, QUESTIONS, Question 256, at 234 (1927). Where an offer of gratuitous assistance is made with the hope of securing future business or in a context giving rise to a suspicion of such motive, it is considered unethical. Asrericsir Bar Assocturront, supro, Opinion 169 (1937), at 342.

Prior to the Button litigation, no court had had occasion to consider the applieability of the rules to activities such as those of the NAACP and the Defense Fund. Since lawyers for these organizations do receive compensation and since, in some cases, litigants do contribute toward expenses, the gratuitous offer, non-commercial context cases are not squarely in point. Nevertheless, considering the commercial target of the rules, the logic of the cases applies with equal force. Sums paid by assisted litigants never amount to more than a small fraction of total costs. Interview with Jack Greenberg, Director-Counsel of the NAACP Legal Defense and Educational Fund, in New York City, December 10, 1962. Thus, neither the organizations nor their attorneys appear motivated by a desire to reap financial benefits. See note 80 infra.

The irrelevance of unauthorized practice rules is less obvious but is clear nevertheless. The purpose of these rules, as applied to bar lay organizations from hiring attorncys to practice law for them, is to prevent commercialization of the profession, deterioration of the traditional attorney-client relationship and possible conflicts of interest between attorney and client. However, although unauthorized practice cases usually arise in the context of a commercial enterprise furnishing legal services to its customers as an 
these doctrines are concerned developed. Thus, throughout the years there has been a constant attempt to minimize undignified competition between lawyers for clients, deterioration of the attorney-client relation, conflicts of interest between attorney and client, and fraudulent or oppressive litigation. Such bar practices as advertising or solicitation by lawyers to secure remunerative business and the writing of wills by trust company attorneys for customers of their employer have been prohibited as encouraging these evils without substantial criticism. But as prohibitions on activity in the legal sphere have infringed on less commercial activity, the validity of the rules has been increas"

accommodation service [see e.g., Richmond Ass'n of Credit Men, Inc. v. Bar Association, 167 Va. 327, 189 S.E. 153 (1937); State Bar Ass'n v. Connecticut Bank \& Trust Co., 145 Conn. 222, 140 A.2d 863 (1958) ], the rule has been applied to activities bearing some resemblance to those of the NAACP. In People $e x$ rel. Courtney v. Association of Real Estate Taxpayers, 354 I11. 102, 187 N.E. 823 (1933), for example, the rule was applied to at nonprofit political-action group organized by Chicago property owners to fight tax laws decmed unfavorable to owners of real estate. In return for annual dues and a small fee, the group agreed to contest members' tax bills in the courts. In declaring that the group had engaged in the unauthorized practice of law, the court dismissed as irrelevant the contention that itsdividual action, considering the comparatively small amount owing by single taxpayers, would have been impractical. Before NAACP v. Harrison, 202 Va. 142, 116 S.E.2d 55 (1960), there appears to have been no case in which the rule was applied to a charitable organization rendering free legal services to the public. As a general rule, however, it has been held immaterial that legal services are rendered free of charge. Grievance Comm, of State Bar v. Dean, 190 S.W.2d 126 (Tex. Civ. App. 1945); Washington Bar Ass'n v. Washington Ass'n of Realtors, 41 Wash. 2d 697, 251 P.2d 619 (1952); State $c x$ rel. Hunter v. Kirk, 133 Neb. 625, 276 N.W. 380 (1937). But see Hexter Title \& Abstract Co. v. Grievance Comm. of State Bar, 142 Tex. 506, 516-17, 179 S.W.2d 946, 952 (1944); Opinion of the Justices, 289 Mass. 607, 615, 194 N.E. 313, 317-18 (1935). In dealing with the problem of unauthorized practice, however, courts have been more flexible than may appear from their dicta. While adhering verbally to the formula that corporations may not "practice law," courts have often recognized competing interests. Where such interests are compelling, courts often evade the issue by finding that the activity does not constitute the "practice of law"; less frequently they admit that the activity in question constitutes the practice of law but refuse to declare it unlawful. Compare Hulse v. Criger, 363 Mo. 26, 247 S.W.2d 855 (1952), with Conway-Bogue Realty Investment Co. v. Denver Bar Ass'n, 135 Colo. 398, 312 P.2d 998 (1957). The uneasiness of courts in such situations is illustrated by an Ohio case which held it unlawful for a title company to sell title opinions, but went on to suggest that it would be "practical' as well as "legal" for the company to grant its lawyers "leaves of absence" and for customers themselves to employ these lawyers to render opinions. Steer v. Land Title Guarantee and Trust Co., 65 Ohio L. Abs. 33, 41, 113 N.E.2d 763, 768 (C.P. 1953).

In the context of organizations such as the NAACP, of course, it could not be held that the services received by sponsored litigants are non-legal. The crucial question would be whether or not lawyers associated with the organization represent litigants in their capacily as private attorneys or in their capacity as employees or associates of the organization. The presence of this question would permit some judicial flexibility. It seems likely that a sympathetic court would adopt the reasoning of a recent Ohio case which held that an in* corporated legal aid society which employed attorneys and charged fees in accordance with litigants' ability to pay was merely an "agency of reference" bringing together attorncy and client and was not "attempting to practice law or in its own interest acting as an intermediary for such purpose." Azzarello v. Legal Aid Society, 185 N.E.2d 566, 570 (Ohio Ct. App. 1962). 
ingly questioned. Thus, when applied to such practices as the conduct of group legal clinics by public-spirited lawyers or labor unions in order to provide low cost legal services for members of the general public or of particular groups, the doctrines have been vigorously assailed as over-protective of professional vested interests. Regulations are then viewed as contributing to an unfortunate and unnecessary public ignorance of legal rights and obligations. ${ }^{76}$

Regardless of their merit as they apply to such quasi-commercial practices, these criticisms forcefully suggest that great caution should be exercised in de-

76. See, e.g., In re Cohn, 10 Ill.2d 186, 196, 139 N.E.2d 301, 306 (1956) (concurring opinion) ; see also Comment, $A$ Critical Analysis of Rules Against Solicilation by Lowyers, 25 U. Cㅍ. L. Rev. 674 (1958); and Brennan, The Bugaboo "Ambulonee Chasing," 6 CAL. S.B.J. 37 (1931). Criticism is especially strong where the rule against unauthorized practice has been applied to bar labor unions from offering free legal services to their members or employers to their employees. See, e.g., DrINRER, LeGAL Eturcs 167 (1957). In this area, there is evidence of widespread evasion and considerable resistance by the bar. Thus, a recent survey indicates that it is a common practice for labor union lawyers to perform personal services for officials and members at union expense. Segal, Labor Union Latuyers: Professional Services of Lawyers to Organized Labor, 5 IND. \& LAB. REL. Rev. 343, 361 (1952). Another poll shows that members of the bar are far from unanimous on the question of whether such conduct is unethical. MeCracken, Report on the Obserianec by the Bar of Stated Professional Standards, 37 VA. L. REv. 399, 400-01 (1951). Citing this latter poll, one writer points out:

The significance of this attitude becomes apparent when it is recognized that the canons of ethics can be fully effective as standards of conduct only if they commend themselves to the members of the bar as reasonable.

Note, The Unauthorized Practice of Law by Lay Organisations Protiding the Services of Attomeys, 72 HARv. L. REv. 1334, 1349 (1959). Although the majority of the bar remains in favor of the rule as applied to labor unions, it is not improbable that this particular application will, as in the case of the recent opposition of the American Afedical Association to the growth of group clinics, succumb to stronger forces. See American Mredical Ass'n v. United States, 317 U.S. 519 (1943), and Comment, The American Mfedical Association: Power, Purpose, and Politics in Organized Mfedicine, 63 Yale L.J. 937, 976-98 (1954).

There is one group of solicitation cases which has also been the subject of special criticism. The cases deal with a program established by the Brotherhood of Railroad Trainmen in 1928 to assist injured members and to prevent over-zealous railroad claims adjusters from securing unconscionable settlements. When an accident occurred, the union's legal department would send investigators to secure evidence and to refer injured members to selected attorneys for prosecution of personal injury and workmen's compensation claims. If litigation proved necessary, the attorneys would take the case on a pre-arranged contingent fee basis. The program has been frustrated by a series of decisions holding it unethical as contrary to the rules against solicitation. In re Brotherhood of Railroad Trainmen, 13 Ill.2d 391, 150 N.E.2d 163 (1958) ; Atchison, T. \& S.F. R.R. v. Jackson, 235 F.2d 390 (10th Cir. 1956) (dictum); Doughty v. Grills, 37 Tenn. App. 63, 260 S.W.2d 379 (1952); Hildebrand v. State Bar, 36 Cal.2d 504, 225 P.2d 508 (1950); Ir re O'Neill, 5 F. Supp. 465 (E.D.N.Y. 1933). Contra, Ryan v. Pennsylvania R.R., 268 Ill. App. 364 (1932). Recently the Supreme Court agreed to review a decision of the Virginia Supreme Court of Appeals in Brotherhood of Railroad Trainmen v. Virginia ex rel. Virginia State Bar (unreported, Aug. 31, 1962), upholding an injunction prohibiting the Brotherhood's legal activitics. 31 U.S.I. WEEK 3255 (U.S. Feb. 19, 1963). For criticism of the cases see Hildebrand v. State Bar, supra at 521, 225 P.2d at 518 (dissenting opinion by Traynor, J.); Drimker, LEGAL ETHICS 161-67 (1957). 
termining the application of doctrines of solicitation and unathorized practice of law to wholly noncommercial activities such as those of the NAACP.77 Certainly NAACP activities do not tend to commercialize the legal profession or impair the dignity of courts. ${ }^{78}$ Because of the absence of pecuniary incentives, the familiar type of conflict of interest problem, typified by the trust company attorney drawing a will for his employer's client, does not arise. And while such organizations do foment litigation (this being in a sense their very raison d'etre), litigiousness is objectionable and normally regulable only becalse of the need to protect private defendants as a class from the vexation and oppression of frequent law suits. ${ }^{70}$ Granted the NAACP and other civil rights litigators are litigious, the fact that their suits are almost always brought against the state or some other governing enterprise renders inapposite state objections on these grounds. Indeed, since the state, as an adversary in such

77. The Canons of Legal Ethics, if they are to remain effective, cannot be applied inflexibly without regard to the evils they are designed to meet or to competing social values. As Harlan Stone remarked :

I would only point out that in the new order which has been forced upon us, we cannot expect the Bar to function as it did in other days and under other conditions. . . . Our canons of ethics for the most part are generalizations designed for an earlier erth. However undesirable the practices condemned, they do not profoundly affect the social order outside our own group. We must not permit our attention to the relatively inconsequential to divert us from preparing to set appropriate standards for those who design the legal patterns for business practices of far more consequence to society than any with which our grievance committees have been preoccupied.

Stone, The Public Influence of the Bar, 48 Harv. L. Rev. 1, 10 (1934). And sec Amurican Bar Association, Opinions of the Commitree on Professional Etritcs and GruevANCES, Opinion 148 (1935), at 308, 312.

78. Indeed, such activities have been responsible for some of the proudest moments in the history of the bar. Refusing to apply the solicitation rule in the case of a lawycr who volunteered his services in defense of a Negro accused of murdering a white family, the court in In re Ades, 6 F. Supp. 467 (D.C. Md. 1934), referred to the many instances where famous men have "solicited" business in this manner-Andrew Hamilton's defense of Jolun Peter Zenger in 1734, Luther Martin's defense of Aaron Burr, and Clarence Darrow's ap)pearance for the defense in Scopes v. Tennessee, 154 Tenn. 105, 289 S.W. 363 (1927), are among those mentioned. In re Ades, supra at 475-76.

79. The concept of litigation as an evil developed in times when courts were easily influenced by the rich and powerful and procedural rules made adjudication largely a contest of wits. This element is noticeable in the considerations which gave rise to one of the original barratry-maintenance statutes-the practice of medieval English lords who brought vexations and groundless suits to blackmail their inferiors and who supported the litigation of their retainers in order to aggrandize their own realms. Radin, Maintchance by Champcrty, 24 CALIF. L. Rev. 48, 64 (1935). Understandably, litigation in those times was regarded ats an evil to which honest men would resort only in extreme circumstances. Intermeddling by a stranger was presumptively immoral.

Today, with changing conceptions of the role of courts in society, the attitude that litigation is necessarily evil has waned. Increasingly it is recognized that "if in medicval England, powerful men oppressed their weaker fellow subjects by maintaining suits against them, in modern society powerful people are more likely to achieve their ends by daring their victims to maintain suits." Radin, supra at 77-78; see also Pound, TuE SH1RT of THE Common Law 134 (1921). 
litigation, is in fact defending the dominant interests from minority attack, the danger of oppression is present only when the state hinders the bringing of lawsuits. Finally, since the activities of organizational litigators were never before thought to be illegal, it would seem difficult to argue that exempting such activities from the prohibitions would open loopholes lessening the effectiveness of the rules in a commercial context.

A finding, however, that the activities of organizational litigators do not create the dangers at which traditional ethical prescriptions are aimed does not mean that no dangers are present which might justify a more narrowly drawn version of the regulation attempted by Virginia. Despite the fact that financial incentives to service of conflicting interests are absent, the danger that ideological commitments may lead an organization to disregard the interests of its litigants cannot be overlooked. Where an organization encourages access to courts primarily for political ends, its policy objectives may influence, in a manner contrary to the interests of those whose litigation it supports, the decisions of the attorneys it provides or recommends of whether and when to sue or take an appeal. Narrow grounds of decision may be forfeited in order to preserve an opportunity to litigate more important issues. While it is improbable, considering the charitable nature of the services involved, ${ }^{80}$ that $\mathrm{cm}$ ployment or compensation by the organization would itself tempt attorneys to act contrary to their individual beliefs and standards, "control" as such by the organization is unimportant. The civil rights attorney will likely share the goals of his organization even before he joins forces with it. And this may be seen to present the conflict problem in a new guise: the attorney may have an active interest conflicting with that of the client; the organization, as a referral mechanism, enhances the chances that litigants will find their way to causeoriented attorneys. ${ }^{81}$ Thus, the likelihood that conflicts of interest will occur is

80. Most organizations rely primarily on volunteer legal services. Attorneys cooperating with the American Civil Liberties Union, for example, are reimbursed for out-of-pocket expenses in sponsored litigation but otherwise serve without fee. AsrericnN Crvin. Liberties Union, 42ND ANnual Report 86 (1962). While the NAACP continues to enjoy the services of eminent volunteers, the increasing volume of litigation in which it participates, particularly in the South, has necessitated the employment of attorneys on a regular basis. Thus, members of the legal staff of the Virginia Conference of NAACP Branches receive $\$ 60$ per diem plus out-of-pocket expenses for their services in connection with sponsored litigation. See note 39 stpra. While this per diem payment is sizeable, it is apparently less than the attorneys normally receive. NAACP v. Button, 371 U.S. 415, 420-21, 444 (1963). And in any case it would seem unlikely, considering the racial situation in the South, that attorneys are attracted to civil rights work by expectation of monetary reward. For an aecount of the difficulties encountered by William L. Higgs-a white attorney who, until recently, represented Negroes in civil rights cases in Mississippi-see Carter, A Loroyer Leaves Mississippi, The Reporter, Vol. 28, No. 10, Mlay 9, 1963, p. 33. It is probable, therefore, that any attempt by the Association to force the hands of its attorneys would result in their leaving the organization.

81. As a practical manner, litigants may be unable to find non-cause-oriented attorneys. Because of the highly-charged racial situation, the Association often provides representation which would otherwise be unavailable. And in this context "cause-orientation" may be 
increased-and it is this danger which may be reduced by a statute barring organizational referral.

In the particular case of the NAACP, however, the danger of prejudice to litigants arising from such conflicts of interest seems largely hypothetical. The Association's objectives are so well-known that many prospective applicants for assistance will probably foresee the extent to which NAACP interests and those of its attorneys conflict with their own. Moreover, the Association is likely to seek litigants with whom it has a complete community of interests. Cases involving relevant issues are not so rare nor test suits so difficult to arrange as to force the Association to resort to the "pirating" of cases in order to pursue its goals; often, assisted litigants are officials of the Association or other persons who themselves have a desire for the adjudiciation of important constitutional issues. The unlikelihood of prejudice to litigants is especially evident in the school segregation suits which make up the greater part of Associationsponsored litigation in Virginia. These suits are almost without exception tried as class actions and generally involve large numbers of plaintiffs. ${ }^{82}$ Although the interests of the Association may not coincide with those of each plaintiff, they are likely to be representative of the class as a whole. Most indicative of the hypothetical nature of the danger of prejudice to litigants in the case of the NAACP is the fact that Virginia, in the Button case, was unable to show a single case of actual prejudice or produce a single litigant dissatisfied with Association service. ${ }^{83}$

Despite the fact that the danger of prejudice arising from conflicting interests is slight in the case of the NAACP, it cannot be dismissed as nonexistent. And regardless of the conclusion one might draw concerning the scruples of the NAACP, the danger remains that other organizations might resort to less wholesome techniques. ${ }^{84}$ The presence of this danger, when considered in the context of Virginia's admittedly high interest in protecting its litigants from prejudice, strongly supports, although it may not compel, Justice Harlan's position that the incidental impairment of first amendment rights which would be wrought by regulation of organizational litigators on this account is justifiable.

a virtue rather than a vice. Consider, for example, the apparent reluctance of southern whitc lawyers to raise the defense of systematic exclusion of Negroes from juries. Sec Note, Negro Defendants and Southern Lawyers: Review in Federal Habcas Corpus of Sysicmatic Exclusion of Negroes from Juries, 72 Y YLE L.J. 559, 561-65 (1963).

82. See note 43 supra.

83. This inability seems to have been largely owing to the Association's prior recognition of the problem and conscious effort to avoid prejudice to litigants. At one of the conferences preceding the restrictive covenant cases, for example, the problem of protecting individual homeowners from injury which might result if lawyers rejected narrow in favor of broad grounds in order to develop a test case, was discussed frankly and at length. Vost, Caucaslans Only 59-60 (1959).

84. The International Labor Defense, for example, has been said to have engaged in a number of questionable practices. See In re Ades, 6 F. Supp. 467, 479-80 (D.C. Md. 1934); Reynolds, Courtroom: The Story of Samuel S. Letbowitz 288-314 (1950). 


\section{A Suggested Approach : Impatrarent of Access to Judicial Redress}

Before adopting a balancing approach, a second perspective on the constitutional propriety of the Virginia legislation may be edifying. It may appear that the statute's almost certain effects give rise to constitutional problems distinguishable from those ordinarily associated with legislation passed in exercise of the state's parens patriae function. Thus, though the statute restricts litigiousness, it is not private defendants who are protected from suit, but the state. And though there may be a largely hypothetical conflict of interest through the organization's asserting broad policy arguments and sacrificing narrow grounds for decision, the state, or its dominant group, has provided substantial protection for itself from the establishment of far-reaching precedent. It is in the execution of what is hypothetically identified as the state's regulatory interest in protecting, not consumers directly, but the functions of its courts, however, that the strongest evidence of ambivalent statutory effect is demonstrated.

Thus, among the hypothetical interests which might be martialed to support the statute against constitutional attack on first amendment grounds are state interests in the proper functioning of courts. The state legislature may be impelled to action by potential interference with the administration of justiceovercrowding of dockets through a proliferation of actions sponsored by persons with only an ideological interest; presentation of cases to the courts, with issues too broadly framed for wise decision, by persons without completely adversary interests; and unwarranted judicial intervention in the political process arising from resort to the judiciary for reasons of expediency rather than necessity. Therefore, it may wish to insure, through legislation, an emphasis upon the passive nature of courts, and the removal of courts from the mainstream of the political process.

The passive aspect of courts has been consistently recognized. As a general rule, decision is based on the narrowest possible ground to avoid premature and possibly unfortunate policy decisions. ${ }^{85}$ It is normally the adversary system which is relied on to churn up all the relevant issues, thus preserving as wide a range of alternative grounds for decision as possible. ${ }^{86}$ Should an organization attempt to force a decision on too broad grounds by suppressing possibly successful lines of argument in the interest of creating precedent, it would be doing a disservice to the court. Here, the same ideological conflict of interest which in other contexts has been seen as endangering litigants may also be viewed as involving possible detriment to the efficient administration of justice. ${ }^{87}$

85. See, e.g., United States v. Rumely, 345 U.S. 41, 45-46, 48 (1953) ; Kovacs v. Brewer, 356 U.S. 604, 607-08 (1958) ; Ashwander v. Tennessee Valley Authority, 297 U.S. 288, 341, 345-48 (1936) (concurring opinion by Mrr. Justice Brandeis).

86. See Bickel, The Least Dangerous Branch 171-72 (1962).

87. Courts have developed techniques of non-decision, rooted in doctrines of standing and ripeness, to resist such imposition of questions too broadly framed for wise decision. See generally id. at 111-98. Despite the availability of these means of judicial self-defense, however, practices which tend to necessitate their use may be viewed as dangerous. 
It is not only by narrowing the grounds available for decision that the activities of organizations such as the NAACP may encourage unwarranted judicial intervention in the political process. Courts, as passive organs, are to decide constitutional questions only as an incident to the decision of cases brought by persons who have themselves suffered some special, direct injury. ${ }^{88}$ But the state may fear that the zeal of litigating organizations will upset the carefully delimited set of circumstances in which cases may be brought before a court for decision. Limitation on court action, rooted in the Constitution, is well-grounded in important policy considerations. ${ }^{80}$ Where no person directly affected by a particular statute or governmental action feels sufficiently aggrieved to seek judicial relief, judicial intervention has seemed unjustifiable. As Professor Frankfurter wrote with regard to the Supreme Court:

The Court is not the forum for a chivalrous or disinterested defense of the Constitution. Its business is with self-regarding, immediate, secular claims. $^{.0}$

On an analogy to the federal requirement of standing, the state legislature might wish to enforce these policies by preventing situations in which organizations, rather than individuals, were the source of litigation activity. The legislature might condemn solicitation broadly since it would be difficult to distinguish organization activity educating citizens in their rights from activity imposing citizens' names upon suits in which they were basically uninterested. ${ }^{.1}$ The suitor's unaided initiative in requesting assistance would, in these

88. The federal judicial power extends only to the decision of cases or controversies. U.S. CoNST., art. III, § 2. It is well settled that this limitation renders the federal courts powerless to render advisory opinions or to decide abstract questions at the instance of persons having only an ideological interest. See, e.g., Massachusetts v. Mellon, 262 U.S. 447, 488 (1923).

89. Limitation on court action is wise not only for reasons of proper judicial administration-the prevention of unwise policy decisions-but also as a matter of democratic theory. The counter-majoritarian nature of the judiciary has been noted. See, c.g., BIcrek, note 86 supra at 16-23; Mason \& Beaney, The Supreme Court in a Free Soctety 318-20 (1959). Judicial intervention in the political process is the deviant rather than the norm. The existence of an aggrieved who has suffered some special injury would seem the basis of any acceptable justification for judicial action. As Professor Bickel has noted:

For the Court to entertain such a suit as Frothingham [See Massachusetts v. Mellon, note 88 supra] and to adjudicate the constitutional issue tendered would, in my judgment, materially alter the function of judicial review and seriously undermine any acceptable justification for it.

BickEL, supra at 122.

90. Frankfurter and Fisher, The Business of the Supreme Court at the October Tarms, 1935 and 1936, 51 HARV. L. REv. 577, 623 (1938).

91. The NAACP frequently has been accused of obtaining authorizations to ste by fraud or payment of bribes. See Murphy, The South Counterattacks: The Anti-NAACP Laws, 12 W. PoL. Q. 371, 375 (1959). While these accusations appear to be untrue, they suggest a danger which may inhere in the activities of all litigating groups. Were such groups to "roam the streets and barrooms" seeking out persons who, though themselves uninterested, were willing to have suits instituted in their names, one seeming function of federal standing rules-the prevention of unwarranted litigation and judicial intervention in the political pro- 
circumstances, permit an inference of minimal personal concern. And on an analogy to the federal court policy of avoiding, where possible, constitutional decision, the state might wish to make clear the impropriety of court action in the political arena.

By selecting and emphasizing one aspect of the functional role of courts, however, the legislature may be ignoring - or intentionally infringing upon-other roles which courts have consistently asserted their duty to play in the mechanism of constitutional government. Through the settling of disputes, courts are able to define statutory or constitutional rules which establish the relationship of citizens to the state. Under the system of constitutional government, courts, especially federal courts, have asserted their role as a check against majorities who are, at particular times, in control of the legislative and executive branches of government. ${ }^{92}$ They thus provide essential protections for minorities institutionally unable to utilize other routes of social change. In this role, courts not only seek to preserve the regular operation of the democratic processes but also act to protect individuals from arbitrary or discriminatory governmental action. Additionally, courts must perform some function as important policymaking institutions. This is especially true in areas, such as civil rights, in which they have special competence. ${ }^{93}$ Oversimplified concepts such as the view that courts merely apply "law" comport neither with reality nor theory. ${ }^{\text {of }}$ In interpreting and applying constitutions and legislative enactments, courts have asserted that they do and should play a significant role in defining the rules which shall govern society.

These latter functions are not important for themselves, but for the protection which they afford to minorities otherwise unable to secure social controls. Prevention of civil rights litigation, since in its trail it brings down performance and, hence, exercise of these functions, deprives minorities of their principal source of protection under the Constitution. Until effectively challenged in the courts, "unconstitutional" legislation remains fully operative and arbitrary or discriminatory governmental practices desired by majorities go unchecked. As a result, while statutes such as the Virginia statute may be viewed optimally as performing legitimate administrative and definitional functions, it is clear that their effects may go directly toward upsetting the institutionalized system of minority safeguards from majority rule, if they substantially reduce the citizens' ability to obtain protection through access to the courts.

cess-would be thwarted. Although this particular objection would not apply where the organization advised persons of their rights, induced in them a desire to sue, and thus secured litigants having a real personal interest, it would be difficult, in practice, to differentiate the two situations.

92. See Mason \& Beaney, The Supreare Court in a Free Socrety 318-20 (1959).

93. Cf. Wellington, Union Democracy and Fair Representation: Federal Responsibility in a Federal System, 67 YALE L.J. 1327 (1958).

94. See Cahill, Judictal Legislation 8-9 (1952); Cardozo, The Nature of tae Judictal Process (1931). 
In the field of civil rights, adjudication of individual claims may require the financial and moral encouragement of public-spirited organizations. Certainly, the Supreme Court has often emphasized a passive aspect through strident articulation of a reluctance to decide constitutional issues not properly presented. ${ }^{.5}$ But, aware of the special problems of civil rights, the Court has not only tolerated but welcomed the participation of civil rights litigators such as the NAACP. During the past three decades these organizations have been responsible for the great buik of important litigation in the field of civil rights. ${ }^{96}$ Given the cost of court action, ${ }^{97}$ the diffuse operation of state invasions of freedom, and the unfortunate unwillingness of the legal profession to provide adequate representation for members of unpopular minorities, ${ }^{08}$ individual action seeking to enforce civil rights may be rendered impossible or improbable by the forces of impersonal "market conditions." In these circumstances, the organizational litigator may be the only agency capable of providing the oppressed with an opportunity to assert their rights in court. The litigating organization has the advantage of a continuing existence. Long-range planning and activity in pursuit of its stated policy goals is usually thus assured. The organization is a convenient marshaling point for the resources of all persons, no matter what degree their interest, and a convenient dissemination point for educational campaigns directed to the public at large. This ability to interact with a relatively broad segment of the community

95. See note 85 supra.

96. See Appendix, infra.

97. Litigation is a costly, if effective, form of political action. Where the state is a party or where important issues are at stake, civil rights cases are likely to be bitterly fought. And where local courts are unsympathetic, even assertions of rights which are well-established may involve appeals to higher tribunals and, thus, large expenditures. The time and cost of prosecuting a single case through to an appeal to the Supreme Court have been estimated at four years and $\$ 10,000$. See Bl.assdelt, American Democracy Under Pressure 263 (1957) ; and Vose, Litigation as a Form of Pressure Group Activity, 319 Annals 20 (1958). In the historic case of Brown v. Board of Education, 347 U.S. 483 (1954), the N.A.A.C.P. Legal Defense and Educational Fund spent more than $\$ 200,000$. NAACP v. Patty, 159 r. Supp. 503, 510 (E.D. Va. 1958). More often than not the expenditure of time and money will prove fruitless: the Supreme Court will deny certiorari, decide on a narrow ground, or render an adverse decision. The legal struggle of the NAACP has been described as

a slow, whittling process wherein courts have usually decided cases on the narrowest possible grounds, thereby enabling individuals and governments to evade the effect of the decision. Renewed work and further expenditure is then necessary to invalidate the discriminatory practice, under each newer and clever disguise, until it is recognized in all its forms as illegal.

Comment, Private Attorneys-General: Group Action in the Fight for Civil Libcrtics, 58 Y ALE L.J. 574, 585 (1949). Quite apparently, litigation by individuals on such a scale is unlikely.

98. See Ernst and Schwartz, The Right to Counsel and the Untpopular Causc, 20 U. Pirt. L. Rev. 727 (1959); and Rostow, The Sovereign Prerogntive: The Suprene Court and the Quest for Law 41 (1962). See also Carter, A Lawyer Leaves Mississippi, The Reporter, Vol. 28, No. 10, May 9, 1963, pp. 33, 34. 
reflects an advantage in gathering the vast resources of money, legal talent, and suitable case material ${ }^{100}$ needed for successful prosecution of policy concerns. Because of these advantages, as contrasted with the inability of individuals to act in their own behalf, organizations have become the established agencies for challenging state deprivations of federal rights. Legislative curtailment of their activities would therefore have the effect of substantially hindering, and in some cases preventing, litigants from securing protection for their fundamental constitutional rights. ${ }^{101}$

In sum, all the apparent dangers-litigiousness, conflict of interests, administration of the courts-which might lead to legitimate legislative concern with activities of groups such as the NAACP arise necessarily from the litigation activities in which they engage-the sponsoring and prosecution of constitutional claims against the state. Legislative regulation, the statement by the state that the dangers will not be tolerated, thus appears to be a statement to the effect that such claims will not be heard, the erection of a barrier of sovereign immunity to constitutional litigation which may in practical effect be nearly complete. This result may imply improper interference with the processes even of the state

99. Felix Frankfurter, Morris L. Ernst, Arthur Garfield Hays, Francis Biddle, Frank: Murphy, and Clarence Darrow are among the distinguished lawyers who have assisted the NAACP. Vose, NAACP Strategy in the Covenant Cases, 6 W. Res. L. REv. 101, 103 (1955).

100. Sociological and economic data may be extremely important in the prosecution of civil rights suits. Statistics developed to show the relation between housing segregation and the development of Negro slums, for example, contributed greatly to the NAACP's success in Shelley v. Kraemer, 334 U.S. 1 (1948). See Vose, Caucasuans OnLy 65-68 (1959). And the now famous footnote eleven of Brown v. Board of Education, 347 U.S. 483, 494-95 n.11 (1954), demonstrates that such data may have a decisive influence. The ready access to university personnel enjoyed by such groups as the NAACP and the American Civil Liberties Union gives them a significant advantage over the private litigant.

101. Absent the litigating activity of organizations such as the NAACP, the performance by courts of their protective and policy-making functions in the area of civil rights would be greatly hindered. This is no less obvious with respect to the policy-malsing function than it is with respect to the protective function. For courts to make policy they need not only cases, but large numbers of cases from which to choose their opportunities. This factor is especially noticeable in constitutional litigation at the United States Supreme Court level, where the certiorari practice, among others, is designed to allow the Court to select cases whose facts and prior histories present the best context in which to formulate policy. In the area of civil rights, courts cannot depend upon individual initiative to supply the requisite volume of litigation. Thus, the energetic, well-financed and insistent litigating activity of organizations such as the NAACP may well be essential if courts are to perform effectively in this area. As Blaisdell has noted:

In policy-making by the judiciary ... it is the readiness of self-conscious groups, under competent leadership and with adequate resources, to appeal to the judicial process which provides the opportunity for the courts to make policy. . . . Can fair rates be fixed and enforced and discriminatory practices prevented on the railronds? The answer turned on the readiness of aggrieved farmers ... as users of transportation to create an opportunity for the courts to make public policy by ruling on the issues.

Blaisdeli, Axterican Dearocracy Under Pressure 265 (1957). 
courts. As a coordinate branch of constitutional government, they might proper ly hold the legislation unconstitutional as applied to bar suits in state courts, arguing that only they and the decision-makers at the level of constitutional amendment ought to have such control over their functional performance. ${ }^{102}$ Ever since Marbury v. Madison, ${ }^{103}$ courts have asserted their authority to decide constitutional cases; legislation which seemingly infringed upon the exercise of this authority might be found objectionable. For federal courts, however, and for the enforcement of federal rights, the practical effect of the Virginia statute, in substantially reducing the opportunity for access, seems a result so objectionable as to make any first amendment balancing inquiry irrelevant.

Access to the federal courts has been said to be a privilege and immunity of national citizenship within that range of federal rights beyond the power of a state to impair. ${ }^{104}$ Thus, the question of access to federal courts is one entirely under the control of the federal courts and legislature. Although state rules may have been adopted in some circumstances, for reasons of convenience, they are adopted only because of their congruity with, and not despite interference with, federal policy. Since Marbury v. Madison, ${ }^{105}$ there has even been substantial question as to the right of Congress to control access, at least at the Supreme Court level $; 106$ it is certainly clear that states would be found without power to foreclose parties from seeking enforcement of federal rights in federal courts by any restriction that those courts would not impose. The citizen's relationship to the Constitution and its enforcement is beyond their regulatory reach. This conclusion, arising from relational rights inherent in the constitutional structure of federalism, draws strength from, but does not depend upon the first amendment. ${ }^{107}$ Given the right of the citizen to enforce his federal rights in state courts, it might also extend to state regulation of state courts, insofar as federal rights are involved in litigation-as they invariably will be in civil rights cases. ${ }^{108}$ Thus any state regulation which has the effect of stibstantially denying access to the courts for the enforcement of fecleral rights, if enforcement is sought in a manner complying with federal policies respecting standing, ripeness, or other similar requirements, is unconstitutional as applied. A

102. That such an argument might prevail in the context of the federal constitutional structure is demonstrated by Professor Hart in Hart \& WeChsler, The Federal Coukrs AND THE FEDERAL SYSTEM 312-13, 317-19 (1953).

103. 5 U.S. (1 Cranch) 137 (1803).

104. See, e.g., Slaughter-House Cases, 83 U.S. (16 Wall.) 36, 79 (1873) ; Terral v. Burke Construction Co., 257 U.S. 529, 532 (1922); and United States v. Lancaster, 44 F. 885 (W.D. Ga. 1896); see also Crandall v. Nevada, 73 U.S. (6 Wall.) 35, 44 (1867).

105. 5 U.S. (1 Cranch) 137 (1803).

106. It is widely assumed that Congress could insulate its legislation from constitutional attack (i.e., totally block access to the courts) through exercise of its powers to create inferior federal courts and to regulate the jurisdiction of the Supreme Court. Professor Hart argues convincingly that the assumption is fallacious. See HART \& WeCrrsLer, note 102 supra, at $312-40$.

107. Cf. Cranda1l v. Nevada, 73 U.S. (6 Wall.) 35 (1867).

108. Cf. Testa v. Katt, 330 U.S. 386 (1947); General Oil Co. v. Crain, 209 U.S. 211 (1908). 
conclusion that a state may not prospectively deny federal constitutional or statutory rights by preventing or unreasonably impeding their enforcement would seem inherent in the concept of due process and constitutional government.

Neither Chapter 33 nor regulations based on the "lay intermediary" character or organizational litigators, of course, would have the effect of totally blocking access to the federal courts or entirely foreclosing the assertion of federal rights. While it is here argued that such regulations would necessarily curtail the activities of litigating organizations substantially, ${ }^{109}$ they would not, in themselves, preclude individual action. And it cannot be asserted that legislation erecting but a partial bar is necessarily unconstitutional. ${ }^{110}$ Relevant in this connection would be the extent of the bar, its compatibility with federal policy, and, to some slight degree, the nature and importance of the state interests protected. These questions, contrary to the apparent implication of Justice Harlan's dissent, would be matters for independent consideration by the Court.111 His argument that "the state policy is not unrelated to the federal rules of standing"112 and thus that "it cannot be argued that the underlying state policy is inevitably inconsistent with federal interests"113 is unpersuasive. In view of the Court's traditional insistence upon making its own determinations in matters of standing, ${ }^{114}$ deference to state legislative judgment here seems entirely out of place. Furthermore, consideration should not be confined exclusively to federal standing policies, but should include the entire range of federal policies. When such consideration is given, any state measure which substantially curtails the activities of organizational litigators would seem clearly inconsistent with federal interests.

If, as is here asserted, Chapter 33 would have substantially curtailed the litigating ability of the NAACP, it would seem that the majority in Button might better have anchored its decision in the effect the legislation would have on access to courts. The first amendment balance is at best imprecise, at least uncertain and indeed may tilt in the state's favor. If it were possible for a state to draft legislation which would protect its citizens and courts from the dangers organizational litigators present and yet not substantially impair their liti-

109. See note 59 sipra.

110. For example, Canon 42 (note 27 supra), by preventing attorneys from paying court costs, obstructs access to both the federal and state courts. It is not here argued, however, that the Canon is unconstitutional for this reason.

111. In dealing with the problem of access, Justice Harlan appears to have based his decision sustaining Chapter 33 on two arguments. The first, that the statute would not have substantially impaired the NAACP's function of vindicating constitutional rights (371 U.S. at 465), is disputed above. See note 60 supra. The second, that the state policy which may have motivated the legislation seems analogous to the federal policy with regard to standing, is ambiguous. The implication, however, is that Harlan considered constitutionally unobjectionable any obstruction of access motivated by a state policy analogous to a federal policy. This would seem not to be the proper test.

112. Ibid.

113. Ibid.

114. Professor Freund has even suggested that the Supreme Court's determination of 
gating effectiveness, constitutional objection to it would seem irresponsible ; it is not clear, however, that such legislation would escape the sweep of Justice Brennan's opinion. A decision based upon the statute's effect upon the assertion of federally guaranteed rights, however, would sharply define the boundaries of permissible state regulation and would involve a principled statement objectionable only to those who repudiate the notion of a federal system. Such an approach, rationalizing all of the Court's recent pronouncements respecting the NAACP, ${ }^{115}$ would have given open recognition to the larger issues presented by the Virginia legislation-that states were seeking to nullify federal law, in this case by striking at those who, as "private attorneys-general," are presently its most effective enforcers.

\section{ApPENDIX}

To determine the extent of group participation in civil rights litigation at the United States Supreme Court level, the Yale Law Journal compiled a list of 318 post-1933 Supreme Court civil rights cases and requested 23 organizations to check those in which they had provided financial or legal assistance, filed amicus briefs, or given strategic advice. The case list included, in addition to others deemed important by the editors, every case printed in whole or in substantial part in either Volume II (on civil rights) of FreUnd, Suritetsland, Howe \& Brown, Constitutionaz Law (Second Ed. 1961) or Emerson \& Hayer, Political and Civil Rights in the United States, Vols. I \& II (Second Ed. 1958). The results of this survey, tabulated from the replies of 13 of the organizations, are shown on the tables below.

It should be remarked that these tables do not reflect the full extent of group participation in Supreme Court civil rights litigation. Since the figures show the activities of but 13 groups (five other groups, the AFL-CIO, the American Friends Service Committec, the National Lawyers Guild, the Protestants and Other Americans United for Separation of Church and State, and the Workers Defense League, failed to submit data; five more, the American Council for Nationalities Service, the American Liberty League [now defunct], the Americans for Democratic Action, the Central Committee for Conscientious Objectors, and the National Urban League, answered that they had participated in none of the cases listed), an allowance should be made for the activities of the many groups and ad hoc committees not included. Also, the list of cases forming the basis of the survey included many of a type only remotely affecting the interests of definable minority groups. It is believed that the percentage participation in certain areas of civil rights (free speech, for example) is somewhat greater than that in the field as a whole. When these factors are taken into account, the percentage figure of 88 for cases printed in both FREUND ET AL., supra, and EMER* SON \& $\mathrm{H}_{\mathrm{ABER}}$, supra, (inclusion in both of these text books would seem to indicate that a case is of special importance) and the percentage figure of 54 overall is impressive.

Information forming the basis of the tables and this discussion was drawn from letters from Osmond Fraenkel, General Counsel of the American Civil Liberties Union, March 27, 1963; Robert Carter, General Counsel of the National Association for the Advancement of Colored People, March 15, 1963; Leo Pfeffer, Director of the Commission on Law and Social Action of the American Jewish Congress, March 13, 1963; Blanch Freedman, Attorney for the American Committee for Protection of the Foreign Born, March 13, 1963; Norman C. Amaker of the N.A.A.C.P. Legal Defense and Educational Fund, March 13, 1963; Leonard Boudin, General Counsel, Emergency Civil Liberties Committec, March 15, 1963; Hayden C. Covington of the Jehovah's Witnesses, March 11, 1963; Oakley C. John-

standing should control the jurisdiction of state courts in federal question suits. Freund, Forzuard: The Year of the Steel Case, 66 HARv. L. Rev. 89, 95 (1952).

115. See note 20 supra. 
TABLE 1

Group Partictration

In Selected Group Of

Supreare Court Civil Rughts Cases

$1933-1963$

\begin{tabular}{|c|c|c|c|c|c|c|}
\hline 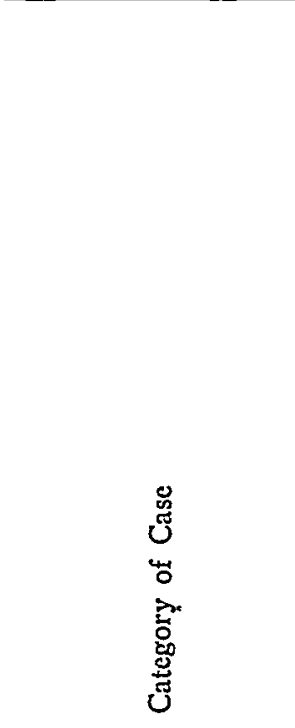 & × & 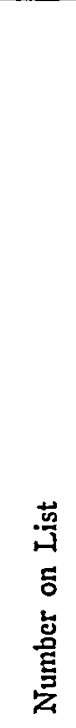 & 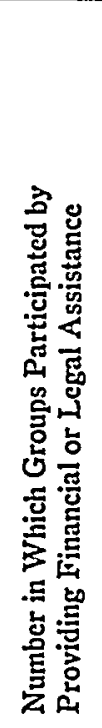 & 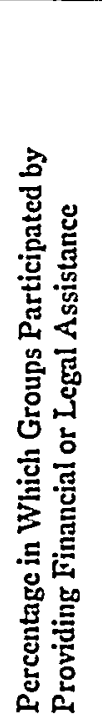 & 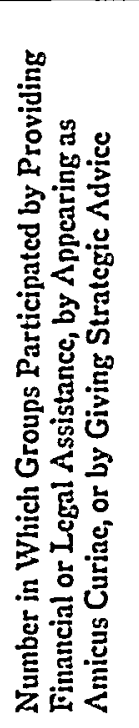 & 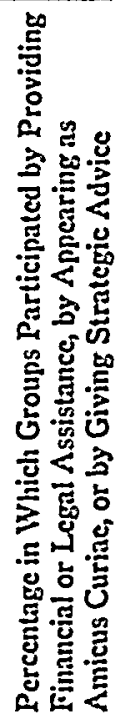 \\
\hline \multirow{2}{*}{$\begin{array}{l}\text { Cases Printed in } \\
\text { Both Freund Et Al. } \\
\text { and Emerson \& Haber }\end{array}$} & $\begin{array}{l}1953 \\
\text { to } \\
1963\end{array}$ & 12 & 5 & $42 \%$ & 12 & $100 \%$ \\
\hline & $\begin{array}{c}1933 \\
\text { to } \\
1963\end{array}$ & 33 & 17 & $52 \%$ & 29 & $88 \%$ \\
\hline \multirow{2}{*}{$\begin{array}{l}\text { Cases Printed } \\
\text { in Freund Et Al. } \\
\text { But Not in } \\
\text { Emerson \& Haber }\end{array}$} & $\begin{array}{c}1953 \\
\text { to } \\
1963\end{array}$ & 43 & 12 & $28 \%$ & 23 & $53 \%$ \\
\hline & $\begin{array}{l}1933 \\
\text { to } \\
1963\end{array}$ & 100 & 26 & $26 \%$ & 44 & $44 \%$ \\
\hline \multirow{2}{*}{ All Others } & $\begin{array}{l}1953 \\
\text { to } \\
1963\end{array}$ & 97 & 32 & $33 \%$ & 50 & $52 \%$ \\
\hline & $\begin{array}{l}1933 \\
\text { to } \\
1963\end{array}$ & 185 & 59 & $32 \%$ & 100 & $54 \%$ \\
\hline \multirow{2}{*}{ Total } & $\begin{array}{l}1953 \\
\text { to } \\
1963\end{array}$ & 152 & 49 & $32 \%$ & 85 & $56 \%$ \\
\hline & $\begin{array}{c}1933 \\
\text { to } \\
1963\end{array}$ & 318 & 102 & $32 \%$ & 173 & $54 \%$ \\
\hline
\end{tabular}


TABLE 2

Participation by Each of Thirteen Groups

iN Selected Group of 318

Supreme Court Cruil Rights Cases

$1933-1963$

\begin{tabular}{|c|c|c|c|c|c|c|}
\hline \multirow[t]{2}{*}{ 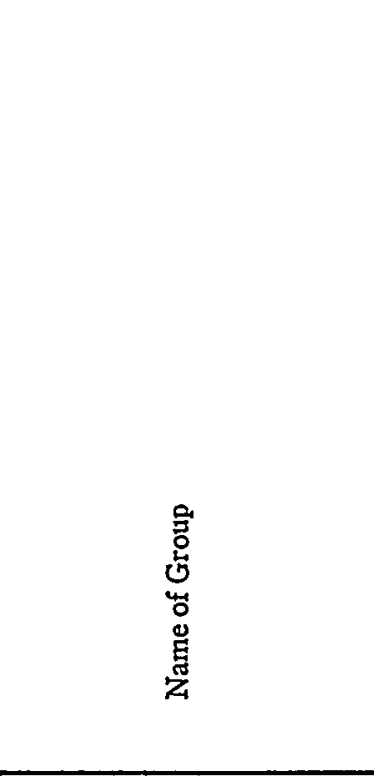 } & 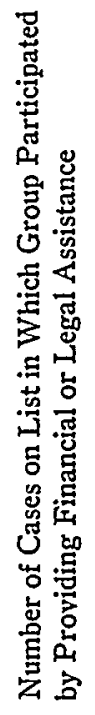 & 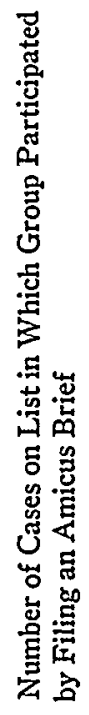 & 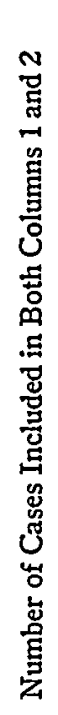 & 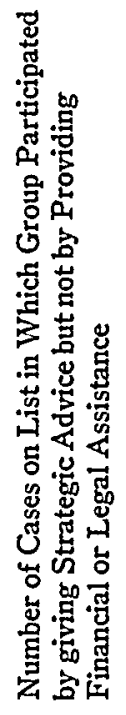 & 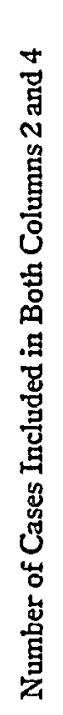 & 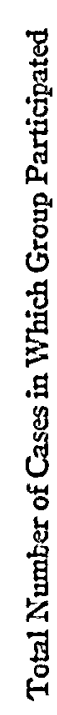 \\
\hline & 1 & 2 & 3 & 4 & 5 & 6 \\
\hline $\begin{array}{l}\text { American Civil } \\
\text { Liberties Union }\end{array}$ & 31 & 81 & 5 & 13 & 0 & 120 \\
\hline NAACP & 23 & 5 & 0 & 2 & 0 & 30 \\
\hline American Jewish Congress & 4 & 22 & 0 & 11 & 8 & 29 \\
\hline $\begin{array}{l}\text { American Committee for } \\
\text { Protection of the } \\
\text { Foreign Born }\end{array}$ & 12 & 2 & 2 & 13 & 0 & 25 \\
\hline $\begin{array}{l}\text { N.A.A.C.P. Legal Defense } \\
\text { and Educational Fund }\end{array}$ & 17 & 3 & 0 & 1 & 0 & 21 \\
\hline $\begin{array}{l}\text { Emergency Civil } \\
\text { Liberties Committee }\end{array}$ & 9 & 5 & 1 & 4 & 0 & 17 \\
\hline Jehovah's Witnesses & 17 & 0 & 0 & 0 & 0 & 17 \\
\hline $\begin{array}{l}\text { Civil Rights Congress } \\
\text { (now defunct) }\end{array}$ & 7 & 0 & 0 & 6 & 0 & 13 \\
\hline American Jewish Committee & 0 & 9 & 0 & 4 & 2 & 11 \\
\hline $\begin{array}{l}\text { Japanese American } \\
\text { Citizens League }\end{array}$ & 7 & 6 & 6 & 0 & 0 & 7 \\
\hline $\begin{array}{l}\text { International Labor } \\
\text { Defense (now defunct) }\end{array}$ & 5 & 1 & 1 & 1 & 0 & 6 \\
\hline $\begin{array}{l}\text { American Book } \\
\text { Publishers Council }\end{array}$ & 1 & 2 & 0 & 0 & 0 & 3 \\
\hline $\begin{array}{l}\text { Association on American } \\
\text { Indian Affairs }\end{array}$ & 0 & 1 & 0 & 0 & 0 & 1 \\
\hline
\end{tabular}


son, Treasurer, Citizens Committee for Constitutional Liberties, March 19, 1963 (reporting on the activities of the Civil Rights Congress and the International Labor Defense); Theodore Leskes of the American Jewish Committee, March 11, 1963; Mrike Mrassola, Washington Representative of the Japanese American Citizens League, March 12, 1963; Horace S. Manges, General Counsel, American Book Publishers Council, March 19, 1963; Arthur Lazarus, Jr., General Counsel, Association on American Indian Affairs, Inc, March 14, 1963; Edith Lowenstein, Editor, Interpreter Releases, American Council for Nationalities Service, March 15, 1963; Earl F. Reed (formerly the head of the National Lawyers Committee of the American Liberty League), March 11, 1963; David Cohen, Legislative Representative, Americans for Democratic Action, March 27, 1963; Arlo Tatum, Executive Secretary, Central Committee for Conscientious Objectors, Afarch 19, 1963, and Alexander J. Allen, Associate Executive Director of the National Urban League, June 24, 1963, all to the Yale Lazo Journal and on file in Yale Law Library. 